\title{
Fragmentation or interaction: the WTO, fisheries subsidies, and international law
}

\author{
MARGARET A. YOUNG * \\ Senior Lecturer, University of Melbourne Law School
}

\begin{abstract}
Subsidies to the fishing sector have trade and ecological consequences, especially for fisheries that are over-exploited. In response, WTO members are negotiating to clarify and improve the Agreement on Subsidies and

Countervailing Measures. Yet significant legal challenges constrain this ongoing effort because fisheries conservation and management matters are often addressed by the United Nations Convention on the Law of the Sea, instruments of the Food and Agriculture Organization, and other legal regimes to which some WTO members have not consented. This article analyses modes of learning and information exchange within the WTO regime, and compares the proposed use of standards, benchmarks, and peer review in the draft fisheries subsidies rules with existing arrangements between the WTO and organizations such as the OECD and product standard-setting bodies. It argues that novel deliberative strategies of regime interaction are more important in resolving the challenges posed by international law's fragmentation than adherence to strict mandates or legal hierarchies.
\end{abstract}

\section{Introduction}

The decision by WTO members to negotiate to clarify and improve fisheries subsidies disciplines signals a new role for the WTO regime in ensuring the sustainability of fish and the fish trade. The WTO joins several existing legal regimes in recognizing the need for multilateral cooperation on fisheries issues to prevent the collapse of global fish stocks, such as the United Nations Convention on the Law of the Sea (UNCLOS), voluntary instruments adopted by the Food and Agriculture Organization (FAO), and regional approaches. These regimes have

\footnotetext{
* Email:m.young@unimelb.edu.au

Much of the research presented here was undertaken during a fellowship at Pembroke College and the Lauterpacht Centre for International Law, University of Cambridge. I am grateful to James Crawford, Ellen Hey, Gary Horlick, Petros Mavroidis, Joanne Scott, Katharine Young and the editor and two anonymous referees for helpful comments, as well as participants at the inaugural conference of the Society for International Economic Law, Geneva, and at the WTO Scholars' Forum at University College London. Thanks are also due to officials and delegates at the WTO and FAO. This article forms part of a wider research project which will be published as Trading Fish, Saving Fish: The Interaction between Regimes in International Law (Cambridge University Press, forthcoming 2010).
} 
responded in various ways to increasingly urgent calls for measures to address the serious decline in wild capture fisheries, where at least $50 \%$ of stocks are fully exploited and $25 \%$ are either overexploited, depleted, or recovering from depletion. ${ }^{1}$ One of the major contributing factors to this crisis is overfishing. ${ }^{2}$

The call for attention to the fishing sector by the WTO regime has come from economists as well as environmentalists. There is increasing recognition that marine fisheries operate globally at a net economic loss. ${ }^{3}$ Perverse incentives to build up an already redundant global fishing fleet capacity, often exacerbated by political pressure for subsidies, ${ }^{4}$ has created economic waste as well as ecological devastation. Much of the fishing sector is heavily supported by states. Although the level of support is difficult to access and quantify, a range of studies indicate that subsidies could amount to a quarter of the value of revenues in the fisheries sector or even higher. ${ }^{5}$ Based on a collection of notifications and data supplied by the countries, Japan provides between US\$2 and \$3 billion annually to its fishing industry. ${ }^{6}$ Significant amounts are also paid out by the European Union, ${ }^{7}$ the United States, Canada, Korea, and China. ${ }^{8}$ While much of this support promotes useful management and conservation techniques, it also risks overfishing through capacity enhancement. Indeed, the size and technological capability of fishing fleets has reached immense dimensions and has helped to ensure that fish is one of

1 FAO, The State of World Fisheries and Aquaculture ('SOFIA') (2006) 33.

2 See Chih-hao Hsieh et al., 'Fishing Elevates Variability in the Abundance of Exploited Species' (2006) 443 Nature 859.

3 World Bank and FAO, The Sunken Billions: The Economic Justifications for Fisheries Reform (2008) 21.

4 See Christopher Carr and Harry Scheiber, 'Dealing with a Resource Crisis: Regulatory Regimes for Managing the World's Marine Fisheries’ (2002) 21 Stanford Environmental Law Journal 45, 54 (noting the special preferences secured by the 'concentrated minority' of commercial fishing interests).

5 For example, OECD countries are estimated to pay USD 6 billion a year to support their fisheries sectors: see OECD, Subsidies: A Way Towards Sustainable Fisheries? Policy Brief (December 2005); developing countries also provided significant support to their fisheries sector: APEC, Study into the Nature and Extent of Subsidies in the Fisheries Sector of APEC Member Economies (2000). The methodology of these papers involved querying governments on their levels of financial support. Stone comments on a study undertaken for the FAO that adopted a different methodology by inferring the level of government support through an industry profile that subtracted gross costs from gross revenues on a global basis, and reported an apparent \$54 billion deficit: see Christopher Stone, 'Too Many Fishing Boats, Too Few Fish: Can Trade Laws Trim Subsidies and Restore the Balance in Global Fisheries?', in Kevin Gallagher and Jacob Werksman (eds.), International Trade and Sustainable Development (2002) 286, 293-294.

6 WWF, Hard Facts, Hidden Problems: A Review of Current Data on Fishing Subsidies (2001) 18 (incorporating notifications to the OECD and the World Bank, and including capital and infrastructure investments, insurance, foreign access payments and measures improving harvesting techniques).

7 The EU has allocated EUR 3.8 billion in subsidies to its fisheries sector over the next seven years: 'Friends of Fish Denounce EU Aid Package', Financial Times (17 June 2006).

8 WWF estimates the US to pay out $\$ 1$ billion annually, and Canada to pay out over $\$ 800$ million annually, based on OECD and APEC data. WWF refers to 'official reports of annual fishing subsidies in Korea' to estimate expenditure there of over $\$ 300$ million, but notes discrepancies with WTO and OECD figures. China's APEC notifications amount to $\$ 50$ million but WWF notes that a number of known subsidy programs are not given monetary values: WWF, above n 6, 18-19. 
the most highly traded food and feed commodities. The value of this trade has reached US $\$ 71.5$ billion, representing at least a $20 \%$ increase over the latest recorded four-year period and a $51 \%$ increase since $1994 .{ }^{9}$ Apart from value increases, the volume of exported fisheries product increased by nearly $8 \%$ from 2002 to $2004 .{ }^{10}$ Thirty-eight per cent of the estimated 142 million tonnes of fisheries and aquaculture production went into exports in 2004. ${ }^{11}$

The attempt by the WTO to discipline fisheries subsidies seems to make environmental and economic sense. Indeed, the express link between the subsidies negotiations and concurrent Doha Round negotiations on trade and the environment acknowledges that the objectives of the new disciplines will be mutually supportive of a range of existing international regimes. Yet the interconnectedness of conservation and trade issues has given rise to significant legal hurdles for WTO members. There is an acute legal problem for the WTO to classify and discipline ecologically harmful subsidies when it has scant institutional or epistemic capacity in this regard. There are problems in the WTO deferring to principles of international fisheries management contained in existing regimes, especially when the WTO membership as a whole has not uniformly approved of such regimes. These problems have beset the framing of the disciplines, and learning and information sharing between regimes has been hindered by restrictive attitudes to observership and participation. In addition, the future implementation and adjudication of subsidies rules faces significant challenges, and there is significant uncertainty about whether organizations like the FAO should have a role in reviewing the fishing practices of subsidizing WTO members.

This article suggests these legal problems can be addressed by moving away from conceptions of strict legal mandates and legal hierarchies, and embracing deliberation and ongoing inter-regime scrutiny by a range of participants. It points to examples from the fisheries subsidies negotiations, as well as existing arrangements in other parts of the WTO covered agreements, to suggest renewed attention to procedures for learning, information-sharing, and multistakeholder deliberation. These procedures have implications for the ongoing effectiveness of the resulting fisheries subsidies disciplines, as well as fragmentation of laws and institutions within the international legal system.

Section 1 introduces regimes that relate to fisheries sustainability, including UNCLOS, the FAO, and the existing framework of the WTO's Agreement on Subsidies and Countervailing Measures (SCM Agreement). It describes ongoing efforts to clarify and improve fisheries subsidies disciplines, with special reference to reactions to the draft proposals circulated in November 2007. Section 2 examines the ongoing challenges for the WTO regime in framing rules and incorporating standards from fisheries regimes. It assesses the legal constraints on

9 SOFIA (2006), above n 1, 41.

10 Figures are based on data from SOFIA (2004) (Part 1) and SOFIA (2006), ibid.

11 SOFIA (2006), above n 1, 3, 7 . 
WTO members, intergovernmental organizations, and other actors in promoting learning about fisheries regimes, subsidy effects, and ecological concerns in the negotiations. It then analyses the proposed regime interaction in the rules themselves and compares existing procedures in the SCM Agreement and SPS and TBT Agreements relating to export credit undertakings and product standards. Section 3 engages with broader themes of governance and considers implications of ongoing deliberation and inter-regime scrutiny for the WTO and international law.

\section{Fragmented fisheries governance and overlapping regimes}

States have historically cooperated on a range of functional and regional issues relating to fisheries, leading to a variety of self-standing laws and principles. These laws and principles can be grouped in 'regimes', a term used to emphasize the contrasting issue areas to which they respond. ${ }^{12}$ In fisheries issues, state expectations have converged under the auspices of several treaties and international organizations, including UNCLOS,${ }^{13}$ the FAO, species-specific and regional fisheries management organizations, and environmental treaties such as the Convention on the International Trade in Endangered Species of Wild Flora and Fauna (CITES). The resulting web of norms and institutions, which were all developed at different times and agreed by differing states, gives rise to problems of co-existence and conflict which are made more complex by the absence of a world legislature. It is part of a general phenomenon known as the 'fragmentation of international law'. ${ }^{14}$

Fragmentation has given rise to a number of challenges in fisheries policy and more generally. For example, there is the potential for states to file parallel proceedings at the International Tribunal of the Law of the Sea and another body, such as the WTO. This occurred in a dispute between the EC and Chile over

12 See, e.g., Stephen Krasner's definition of 'regimes' as 'sets of implicit or explicit principles, norms, rules, and decision-making procedures around which actors' expectations converge in a given area of international relations': 'Structural Causes and Regime Consequences: Regimes as Intervening Variables', in Stephen Krasner (ed.), International Regimes (1983) 1, 3. Krasner's 'actors' are impliedly sovereign states, although the other contributors to this volume do incorporate perspectives of transnational elites (see, e.g., Oran Young, 'Regime Dynamics: The Rise and Fall of International Regimes', in that volume at 93). The International Court of Justice applied the concept of 'self-contained regime' to distinguish a set of specific international rules from general international law in Case Concerning the United States Diplomatic and Consular Staff in Tehran (United States of America v Iran) [1980] ICJ Reps 41 at para. 86, discussed in Bruno Simma, 'Self-Contained Regimes' (1985) 16 Netherlands Yearbook of International Law 111.

13 Entered into force in 1994; currently 157 parties http://www.un.org/Depts/los/convention agreements/convention_agreements.htm (as at 4 December 2008). A notable non-party is the United States of America.

14 As discussed by the International Law Commission (ILC), 'Report of the Study Group, Fragmentation of International Law: Difficulties arising from the Diversification and Expansion of International Law: Conclusions' (A/CN.4/L.702) (18 July 2006); see also 'Analytical Study' finalized by the Chairman (A/CN.4/L.682 and Corr.1) (13 April 2006). 
swordfish landings. ${ }^{15}$ In addition, courts and tribunals may find it necessary to interpret laws within one regime by reference to laws that have been developed within another regime. This occurred most famously in a WTO dispute over a US import ban on shrimp. ${ }^{16}$

Recent literature on the fragmentation phenomenon has concentrated on situations where international norms come into relationships of conflict or interpretation. ${ }^{17}$ This problem is usually manifest at the stage of dispute settlement in international law, when states have already negotiated and implemented relevant laws. In providing recommendations for states, a Study Group of the International Law Commission (ILC) recently published a 'toolbox' of relevant principles to provide guidelines for legal practice. ${ }^{18}$ The ILC pointed to principles such as the rule of lex specialis, according to which a more specific treaty will usually trump the general treaty, ${ }^{19}$ in order to find the true intent of the state parties in these situations.

Less attention, however, has been given to the impact of fragmentation on the making of international rules, and the ILC Study Group concluded that there was a need for greater analysis of 'the notion and operation of "regimes"'. ${ }^{20}$ Indeed, in the context of WTO rules on fisheries subsidies, there is considerable uncertainty about how regimes should interact in their formulation as well as their future application. There is as much scope for international lawyers to contribute understanding and ideas about collaboration and cohesion in rule making within regimes as there is in a focus on ex post rules determining priority in later disputes. An analysis of regime interplay during rule making may even contribute to a different understanding of conflicting norms and of the way regimes interact after rules are made. To introduce this discussion, the remainder of this section provides an overview of the main regimes of relevance to the fisheries subsidies negotiations.

\section{Law of the sea and 'optimum utilization'}

UNCLOS promotes an objective of 'optimum utilization' of fisheries. Its greatest impact on fisheries governance has been the recognition that the exclusive economic zone (EEZ) of states extends to 200 nautical miles. ${ }^{21}$ As a result, $90 \%$

15 See Marcos Orellana, 'The Swordfish Dispute between the EU and Chile at the ITLOS and the WTO' (2002) 71 Nordic Journal of International Law 55.

16 Appellate Body Report, United States - Import Prohibition of Certain Shrimp and Shrimp Products WT/DS58/AB/R (circulated 12 October 1998).

17 ILC Conclusions, above n 14, Conclusion (2), 7-8; see also Joost Pauwelyn, Conflict of Norms in Public International Law: How WTO Law Relates to Other Rules of International Law (2003). For a sceptical perspective influenced by systems theory, see Andreas Fischer-Lescano and Gunther Teubner, 'Regime-Collisions: The Vain Search for Legal Unity in the Fragmentation of Global Law' (2004) 25 Michigan Journal of International Law 999.

18 Ibid., 2.

19 According to the same principle, a more specific regime will usually have priority over general international law: ibid., Conclusion (5), 8-9; Conclusions (11)-(16), 12-13.

20 Ibid.

21 See UNCLOS, Art. 55-75, esp. Art. 57. 
of fish resources are now located within the national jurisdiction of coastal states. ${ }^{22}$ Broadly speaking, there are two main ways a state 'utilizes' the fish within its EEZ: (1) by allowing their own registered vessels to fish within these areas; or (2) by granting access to other states, having had regard to the rights of land-locked and geographically disadvantaged states. ${ }^{23}$ Many of the states that procure such access have large vessel capacity that has historically been used in their own coastal areas or in distant waters. The European Union, for example, has entered into 20 bilateral fishing agreements, primarily with developing countries in Africa, which allow EU vessels to fish within the EEZs of these countries. $^{24}$

The remainder of the oceans outside the EEZs continues to be classified as 'high seas' ${ }^{25}$ These areas contain a number of highly migratory species of significant commercial value, in addition to 'straddling stocks' which move back and forth across EEZ boundaries. There is significant competition between states to fish for these species and disincentives for such states to adopt conservation measures that could benefit 'free-riding' states. As such, these species are especially vulnerable to 'the tragedy of the commons'. ${ }^{26}$

UNCLOS provides that all states will continue to enjoy the traditional freedoms of fishing in the high seas, but this right is qualified by the need to conserve living resources ${ }^{27}$ States whose nationals fish in the high seas are expected to cooperate to conserve and manage living resources and to establish regional institutions for this purpose. ${ }^{28}$ Similarly, coastal states and fishing states whose vessels move between EEZs and the high seas in order to catch highly migratory species, such as tuna, are to cooperate through relevant organizations. ${ }^{29}$ These 'regional fisheries management organizations' (RFMOs), some of which had existed before

22 William Burke, The New International Law of Fisheries: UNCLOS 1982 and Beyond (1994) 23.

23 UNCLOS, Art. 69-70; see also Art. 71.

24 An example is the recently renegotiated agreement between the EU and Mauritania, under which the EU will pay EUR 75.25 million a year to catch 250,000 tonnes of fish species, including octopus, crab, crawfish, sardines, anchovies and lobster, from 1 August 2008 to 31 July 2012: see (2008) 8:5 Bridges Trade and Biological Resources News Digest. For a criticism of the exploitative effect of these arrangements, with a particular focus on the EU-Senegalese fishing relations, see Emma Witbooi, 'Governing Global Fisheries: Commons, Community Law and Third-Country Coastal Waters' (2008) 17(3) Social and Legal Studies 369.

25 UNCLOS, Arts. 116-120.

26 See theories developed from the premise most famously described by Hardin, where multiple users face disincentives in adopting conservation measures that might benefit free-riding competitors: Garrett Hardin, 'The Tragedy of the Commons' (1968) Science 1243. For arguments against the inevitability of tragedy, see Elinor Ostrom, Governing the Commons: the Evolution of Institutions for Collective Action (1990) (analysing conditions that alleviate commons tragedy such as the ability of individuals affected by relevant rules to participate in modifying the rules and monitoring of compliance).

27 UNCLOS, Art. 116-119. This was the basis of Chile's claim in the swordfish dispute: see above n 15 .

28 Ibid., Art. 118.

29 UNCLOS, Art. 64. 
UNCLOS was agreed,${ }^{30}$ now number over $20 .{ }^{31}$ Some are specific to species; others are based on regions. ${ }^{32}$

A major problem of UNCLOS has been that even if conservation measures are developed within RFMOs, some nationals reflag their vessels to register them with non-member states that offer 'flags of convenience' ${ }^{33}$ In addition, many vessels (including those flying flags of convenience and those that are authorized) are increasingly involved in fishing that is illegal, unreported, and unregulated. ${ }^{34}$

In 1995, attempts to improve the management of the high seas culminated in a new 'Fish Stocks Agreement ${ }^{35}$ which has been ratified by over 70 countries. The Fish Stocks Agreement applies to highly migratory fish stocks and fish stocks that straddle the high seas and EEZs. ${ }^{36}$ It provides that parties who fail to become members of an existing regional regime and refuse to apply conservation and management measures can be denied access to the relevant fishery. ${ }^{37}$

As is clear from the brief description given above, the law of the sea regime's achievement of 'optimal utilization' depends heavily on the institutions within which states cooperate on conservation and management measures. Both UNCLOS and the Fish Stocks Agreement rely on existing or to-be-established RFMOs for implementation and management. ${ }^{38}$ Unfortunately, however, many RFMOs suffer from problems in restraining overfishing. ${ }^{39}$ In addition to this lack

30 Robin Churchill and Vaughan Lowe, The Law of the Sea (3rd edn, 1999) 296-305.

31 Tore Henriksen, Geir Hønneland, and Are Sydnes, Law and Politics in Ocean Governance: the UN Fish Stocks Agreement and Regional Fisheries Management Regimes (2006) 3.

32 An example of the former is the International Commission for the Conservation of Atlantic Tunas (ICCAT); an example of the latter is the Commission for the Conservation of Antarctic Marine Living Resources (CCAMLR).

33 One description amongst many of the problem of flag-states is contained in Richard Herr, 'The International Regulation of Patagonian Toothfish', in Olav Schram Stokke (ed.), Governing High Seas Fisheries: The Interplay of Global and Regional Regimes (2001) 303.

34 This phenomenon - known by the acronym 'IUU' - occurs when resources of both EEZs and the high seas are plundered without effective flag state control; see further below n 54 and surrounding text.

35 Agreement for the Implementation of the Provisions of the United Nations Convention on the Law of the Sea of 10 December 1982 relating to the Conservation and Management of Straddling Fish Stocks and Highly Migratory Fish Stocks; see further http:/www.un.org/Depts/los/convention_agreements/ convention_agreements.htm (last accessed 4 December 2008). Some parties are not parties to UNCLOS: see e.g. USA.

36 Fish Stocks Agreement, Art. 3.

37 Ibid., Art. 8(3) and (4). It also provides for the application of a precautionary approach to the conservation, management, and exploitation of straddling fish stocks and highly migratory fish stocks: Art. 6. For interpretation of this provision by five selected RFMOs, see Henriksen et al., above n 31, 197-199.

38 See especially UNCLOS, Art. 64 (highly migratory species); Art. 118 (high seas); Fish Stocks Agreement, Art. 8(1).

39 M. J. Peterson, 'International Fisheries Management', in Peter Haas, Robert Keohane, and Marc Levy (eds.), Institutions for the Earth: Sources of Effective International Environmental Protection (1993) 249, 300. See also SOFIA (2006), above n 1, 7. ('Strengthening RFMOs in order to conserve and manage fish stocks more effectively remains the major challenge facing international fisheries governance.') 
of regional support, there is little direct support at the international level. The UN Division for Ocean Affairs and the Law of the Sea provides advice and research on the implementation of UNCLOS, but does not have specific functions relating to fisheries. ${ }^{40}$ The General Assembly of the UN has a broad oversight and makes annual resolutions but is not involved in any specific monitoring of treaty implementation or compliance. ${ }^{41}$ The only other international institution is a UN specialized agency that seeks to improve 'the efficiency of the production and distribution of all food and agricultural products': the FAO. ${ }^{42}$

\section{The FAO instruments and 'responsible fisheries'}

The reliance on coastal states and RFMOs to control the exploitation and development of fisheries within the law of the sea regime has largely failed to secure responsible fisheries management. Advocacy for a different approach to fisheries management and conservation has taken place within the FAO, where members have sought to establish principles and standards within a voluntary 'soft-law' framework. States do not need to be a party to UNCLOS to be a member of the FAO, and indeed some have joined the FAO without agreeing to UNCLOS. ${ }^{43}$

The FAO collects and publishes fisheries data ${ }^{44}$ and provides institutional support for the negotiation and ongoing revision of a range of instruments, including binding agreements, voluntary codes, plans of actions, and technical guidelines. It is made up of several governing bodies, including sectoral committees such as the Committee on Fisheries in which members may apply to participate. ${ }^{45}$

40 See excerpts from the Secretary-General's Bulletin ST/SGB/1997/8 available at http://www.un.org/ Depts/los/doalos_activities/about_doalos.htm (last accessed 4 December 2008). For a brief overview, see Louise de La Fayette, 'The Role of the United Nations in International Oceans Governance', in David Freestone, Richard Barnes, and David Ong (eds.), The Law of the Sea: Progress and Prospects (2006) 63.

41 The onus is on states to complain about lack of treaty compliance of other states: see Richard Barnes, 'The LOSC: An Effective Framework for Domestic Fisheries Conservation?', in David Freestone et al. (eds.) (2006), above n 40, 233, 259, and citations therein.

42 FAO Constitution, Preamble; see also Art. XVI. ('In this Constitution the term "agriculture" and its derivatives include fisheries, marine products, forestry, and primary forestry products'.)

43 See, e.g., United States is a member of the FAO but not UNCLOS. There are currently 151 Member Nations of the FAO, one 'Member Organization', the European Community, and one 'Associate Member': see http://www.fao.org/unfao/govbodies/membernations3_en.asp (last accessed 4 December 2008).

44 See, e.g., the biennial SOFIA, which depends heavily on inputs from domestic agencies (and excludes certain data where there are indications that production statistics are too high): SOFIA (2006), above $\mathrm{n} 1,5$.

45 The FAO Committee on Fisheries ('COFI') was established in 1965 and membership currently numbers 104: see http://www.fao.org/unfao/govbodies/fishfinal_en.asp (last accessed 4 December 2008). The responsibility of COFI, as the 'only global intergovernmental forum' on fishery issues, is to review work programmes, conduct periodic general reviews of international fishery problems, and examine possible solutions ' with a view to concerted action by nations, by FAO, intergovernmental bodies and the civil society': http://www.fao.org/fishery/about/cofi (last accessed 4 December 2008). COFI may also establish sub-committees on certain specific issues; in 1985, it established the Sub-Committee on Fish Trade, and, in 2001, the Sub-Committee on Aquaculture. 
In seeking to address the reflagging of fishing vessels into flags of convenience, FAO members adopted in 1993 a 'Compliance Agreement'. ${ }^{46}$ Two years later, the FAO conference adopted the Code of Conduct for Responsible Fisheries ('Code of Conduct'), which sought to engage with technical, socio-economic and environmental factors relating to sustainable fishing. ${ }^{47}$ Reiterating the duty of states to cooperate through regional institutions, ${ }^{48}$ the Code of Conduct is also directed at fishing entities, NGOs, and persons including 'fishers, those engaged in processing and marketing of fish and fishery products and other users'. ${ }^{49}$ Voluntary 'International Plans of Actions' ('IPOAs') provide further elaboration of the Code of Conduct for specific species and issues.

The FAO Code of Conduct recognizes the problem that there are too many boats fishing for too few fish. It provides that states should take measures 'to ensure that fishing effort is commensurate with the productive capacity of the fishery resources and their sustainable utilization'. ${ }^{50}$ This is not simply preventative: the Code recognizes that excess fishing capacity needs to be 'eliminated'. ${ }^{51}$ States' management measures are to provide that 'the economic conditions under which fishing industries operate promote responsible fisheries' ${ }^{52}$

Although the Code of Conduct does not mention subsidies expressly, two IPOAs call on states to reduce subsidies which contribute to the build-up of excessive fishing capacity: the IPOA for the Management of Fishing Capacity ('IPOACapacity'), which was adopted in $1999,{ }^{53}$ and the IPOA to eliminate illegal, unregulated and unreported fishing ('IPOA-IUU'). ${ }^{54}$

The FAO's IPOA-Capacity calls upon states to 'reduce and progressively eliminate all factors, including subsidies and economic incentives ... which contribute, directly or indirectly, to the build-up of excessive fishing capacity' ${ }^{55}$ Supported by information on subsidies to be gathered by the $\mathrm{FAO},{ }^{56}$ states are to achieve

46 Agreement to Promote Compliance with International Conservation and Management Measures by Fishing Vessels on the High Seas, adopted by the FAO Conference in 1993 and entered into force in 2003: see further http://www.fao.org/Legal/treaties/012s-e.htm (last accessed 4 December 2008).

47 FAO Code of Conduct, Art. 3.2(c). For the background and elaboration of the Code of Conduct, see http://www.fao.org/DOCREP/005/v9878e/v9878e00.htm\#BAC.

48 Ibid., Art. 6.12.

49 Ibid., Art. 1.2.

50 Ibid., Art. 6.3; see also Art. 7.4.3.

51 Ibid., Art. 7.1.8; see also Art. 7.6.3.

52 Ibid., Art. 7.2.2.

53 See http://www.fao.org/fishery/ipoa-capacity/en (last accessed 4 December 2008).

54 See http://www.fao.org/DOCREP/003/y1224e/y1224e00.HTM (last accessed 4 December 2008). The concept of IUU, introduced above n 34 and surrounding text, is defined by the IPOA-IUU at para. 3 . The definition includes illegal fishing within EEZs or within high seas governed by RFMOs and unregulated fishing in areas where there are no applicable conservation or management measures 'and where such fishing activities are conducted in a manner inconsistent with State responsibilities for the conservation of living marine resources under international law'.

55 IPOA-Capacity, para. 256.

56 Ibid., para. 45. 
capacity reduction in four ways: (1) by conducting national, regional, and global assessments of capacity; (2) by preparing and implementing national plans; (3) by strengthening RFMOs; and (4) by undertaking immediate action for major straddling, highly migratory and high seas fisheries. ${ }^{57}$ To date, only two states have submitted 'national plans of action' on capacity to the FAO: the United States and Namibia.

The FAO's IPOA-IUU also refers to subsidies. It calls on states to 'avoid conferring economic support, including subsidies, to companies, vessels or persons that are involved in IUU fishing', but only 'to the extent possible in their national law' ${ }^{58}$ The plan provides that the FAO will have a role in collecting relevant information and analysis on subsidies practices. ${ }^{59}$ To date, national plans on combating IUU fishing have been notified by Australia, Canada, Chile, Korea, New Zealand, and the United States. ${ }^{60}$

The voluntary approach to subsidies reduction has largely failed to change national policies and has failed to alleviate the overfishing and economic drain in the fishing sector. At the World Summit on Sustainable Development in 2002, states were reminded that to achieve sustainable fisheries they must ratify or accede to UNCLOS and the Fish Stocks Agreement, effectively implement the FAO Code of Conduct, and urgently develop and implement national and regional plans of action, in particular the IPOA-Capacity (by 2005) and the IPOA-IUU (by 2004). ${ }^{61}$ For the elimination of subsidies contributing to IUU fishing and overcapacity, however, attention had moved from the law of the sea regime and FAO instruments. Instead, states were called upon to improve relevant parts of a legal regime that directly confronts the national policies of subsidizing states: the World Trade Organization. ${ }^{62}$

\section{WTO subsidies disciplines}

The weakness of the law of the sea and FAO regimes in addressing the economics of the fishing sector has led to increased attention on the WTO regime and, in particular, on its disciplines on subsidies. Members have agreed to clarify and improve the SCM Agreement's disciplines as part of the Doha Round.

57 IPOA-Capacity, para. 8.

58 IPOA-IUU para. 23.

59 Ibid., para. 88 .

60 In addition, regional plans have been notified by the European Commission and the Lake Victoria Fisheries Organization: see http://www.fao.org/fishery/publications/iuu/npoa (last accessed 4 December 2008). The Committee of Fisheries has separately endorsed a plan for a new legally binding instrument to combat IUU fishing based on the use of port state measures. It has also discussed the use of monitoring, control and surveillance, including from satellite systems: see further FAO, Report of the Twenty-Seventh Session of the Committee on Fisheries (FAO Fisheries Report No 830, 2007), para. 63-72.

61 UN, 'Plan of Implementation of the World Summit on Sustainable Development' (A/CONF.199/ 20) (4 September 2002), para. 31.

62 Ibid. 


\section{The SCM Agreement}

The WTO SCM Agreement disciplines the use by WTO members of certain subsidies that are specific to enterprises or industries and regulates the actions other WTO members can take to counter the effects of such subsidies. It categorizes subsidies as prohibited, actionable, or non-actionable. These categories are often described by mixing a traffic light metaphor: the prohibited subsidies are 'redbox', actionable subsidies are 'amber-box' and non-actionable subsidies are 'green-box'. The green-box, which includes subsidies for the adaptation of existing facilities to environmental sustainability, has lapsed under the existing SCM framework. ${ }^{63}$

WTO members have so far been unwilling to challenge the fisheries subsidies of another WTO member under the SCM Agreement. On the one hand, it is fairly certain that most government support to the fishing sector will be 'deemed' to be a subsidy. ${ }^{64}$ On the other hand, the breadth of practice of granting fisheries subsidies may mean that WTO members are reluctant to expose themselves to scrutiny when pursuing claims. ${ }^{65}$ Indeed, even if WTO members do not provide subsidies themselves, they may indirectly benefit from subsidies of other members which are used to procure access rights for fleets to fish in distant water EEZs. Such rights, for example, are sometimes obtained by WTO members through non-financial arrangements, such as the provision of preferential trade incentives. ${ }^{66}$

The absence of any litigation on fisheries subsidies may, instead, be attributed to a lack of certainty about the applicability of the red-box and amber-box disciplines of the SCM Agreement, as currently framed. Current red-box subsidies are those subsidies that are contingent on export performance or the use of local content. ${ }^{67}$ Because the majority of fisheries subsidies are granted by countries such as Japan that are net importers of fish, and are usually designed to encourage domestic fish supply rather than exports, the red-box test is said to be difficult to meet in many cases. Also ill-suited is the red-box's emphasis on ex-ante legal design rather than effects. $^{68}$

63 SCM Agreement, Art. 8, 9. The provision was adopted on a provisional basis for a period of five years: SCM Agreement, Art. 31. When it expired on 31 December 1999, a lack of consensus among WTO members meant that it was not renewed.

64 A subsidy is 'deemed' to exist under the SCM Agreement if there is a 'financial contribution' by a government or public body that confers a benefit on any domestic industry: see SCM Agreement, Art. 1.1(1).

65 See Marc Benitah, 'Ongoing WTO Negotiations on Fisheries Subsidies', ASIL Insight (June 2004).

66 As described with reference to the EU practice in obtaining fishing rights in several African EEZs: see above $\mathrm{n}$ 24. It is unsettled whether these subsidies fall within the current definition of the SCM Agreement Art. 1. For a supporting argument, see David Schorr, 'Towards Rational Disciplines on Subsidies to the Fishery Sector: A Call for New International Rules and Mechanisms', in WWF, The Footprint of Distant Water Fleets on World Fisheries (1998).

67 SCM Agreement, Art. 3; see also Art. 2 and Art. 1.2.

68 But note that the SCM Agreement prohibits subsidies that are contingent on export or domestic supply 'in law or in fact': ibid. (emphasis added). As such, effects may become relevant; see further David 
The actionable subsidies of the amber-box, on the other hand, are assessed according to their adverse effects on the trade interests of other WTO members. These subsidies, which must also be specific to a particular enterprise or industry, ${ }^{69}$ are assessed according to injury to the domestic industry of another member, the nullification or impairment of benefits of another member, or serious prejudice to the interests of another member. ${ }^{70}$ The establishment of these adverse effects is difficult in the fisheries context, however, given that the likely distortions caused by fisheries subsidies will be in resource availability, rather than price for exporters, and that such effects are spread over heterogeneous fisheries products. ${ }^{71}$

A further deficiency for the disciplining of fisheries subsidies under the current framework relates to inadequate compliance with the SCM Agreement's notification and surveillance regime. WTO members are obliged to notify the WTO annually of any subsidy granted or maintained, ${ }^{72}$ yet fisheries programmes are apparently underreported and the WTO lacks meaningful data for the fisheries sector. ${ }^{73}$

Discussion between WTO members about the need to address fisheries subsidies, and the possible inadequacies of the SCM Agreement, took place in the Committee on Trade and Environment (CTE) in the 1990s. Although the linkage between trade and environmental policies is often considered sceptically given perceived problems of effectiveness ${ }^{74}$ the disciplining of fisheries subsidies falls squarely within the available measures and objectives of the WTO. In 2001, WTO members launched the Doha Round of negotiations, and included fisheries subsidies on the agenda for reform.

\section{The Doha negotiations}

WTO members have agreed to negotiate to 'aim to clarify and improve WTO disciplines on fisheries subsidies, taking into account the importance of this sector to developing countries', as part of a wider scale reform of the SCM and AntiDumping Agreements. ${ }^{75}$ The negotiations have been assigned to the Negotiating Group on Rules ('Rules Group'), which reports to the WTO's Trade Negotiations Committee.

WTO members have acknowledged the environmental dimension to the fisheries subsidies negotiations by referring to the mutual supportiveness of trade and

Schorr, Healthy Fisheries, Sustainable Trade: Crafting New Rules on Fishing Subsidies in the World Trade Organization (WWF Position Paper, 2004) 39.

69 SCM Agreement Art. 1.2, Art. 2.

70 SCM Agreement, Art. 5.

71 See generally WTO Docs TN/RL/W/3 and TN/RL/W12.

72 SCM Agreement, Art. 25.

73 See, e.g., WTO Docs TN/RL/W3, para. 8; WTO Doc TN/RL/M/7, para. 23; WTO Doc TN/RL/M/ 8, para. 39 .

74 See Peter Lloyd, 'When Should New Areas of Rules be Added to the WTO?' (2005) 4 World Trade Review 275.

75 WTO Ministerial Declaration adopted on 14 November 2001 (WT/MIN(01)/DEC/1, 20 November 2001), para. 28. 
environment. ${ }^{76}$ The link between the trade-distorting and environmental harmful aspects of fisheries subsidies has been restated in the course of the negotiations. The Ministerial Declaration at the Hong Kong meeting of trade ministers in 2005 states that Ministers

recall our commitment at Doha to enhancing the mutual supportiveness of trade and environment, note that there is broad agreement that the Group should strengthen disciplines on subsidies in the fisheries sector, including through the prohibition of certain forms of fisheries subsidies that contribute to overcapacity and over-fishing, and call on Participants promptly to undertake further detailed work to, inter alia, establish the nature and extent of those disciplines, including transparency and enforceability. Appropriate and effective special and differential treatment for developing and least-developed Members should be an integral part of the fisheries subsidies negotiations, taking into account the importance of this sector to development priorities, poverty reduction, and livelihood and food security concerns. ${ }^{77}$

In November 2007, the Chair of the Rules Group, Ambassador Guillermo Valles Games, circulated a draft consolidated text of the proposed disciplines ('Chair's text'). ${ }^{78}$ The Chair's text is in the form of an annex ('Annex VIII') of the SCM Agreement. Since then, there have been several meetings in which some WTO members have criticized various aspects of the Chair's text. These criticisms have been summarized in a draft document issued on 28 May $2008,{ }^{79}$ which describes the difficulties in making effective rules that still address development priorities, poverty reduction, and food security concerns. The Chair tabled a 'roadmap' of key issues rather than a new draft text on 19 December $2008 .^{80}$

Two main positions have been taken by the Rules Group participants leading up to the Chair's text. The first position, associated with an informal grouping of WTO members self-named 'Friends of Fish', ${ }^{81}$ is based on a conviction of the link between enhanced subsidy disciplines and trade, environmental and development needs. ${ }^{82}$ These countries have proposed a general prohibition of all fishery subsidies that support fishing enterprises with limited exceptions. Exceptions to this prohibition, which would be identified and defined during the negotiations, would relate to subsidies that are expressly concerned not to encourage overfishing, such

76 Ibid., see reference in para. 28 to para. 31 .

77 WT/MIN(05)/DEC (adopted on 18 December 2005), Annex D, para. 9.

78 Draft Consolidated Chair Texts of the AD and SCM Agreements, WTO Doc TN/RL/W/213 (30 November 2007), Annex VIII to the SCM Agreement (87-93).

79 WTO Doc TN/RL/W/232 (Annex C - Fisheries Subsidies).

80 WTO Doc TN/RL/W/237 (19 December 2008).

81 Membership varies according to time and the content of submissions. Members have included Australia, Chile, Ecuador, Iceland, New Zealand, Peru, Philippines, and the United States.

82 This perspective has been elaborated in a number of papers to the CTE and later the Rules Group. See, e.g., WTO Docs TN/RL/W/3, TN/RL/W/12, TN/RL/W/21, TN/RL/W/58, TN/RL/W/77, TN/RL/W/ 154, TN/RL/W/166, TN/RL/W/169, TN/RL/W/196, and TN/RL/GEN/145. 
as subsidies to decommission vessels and support social programmes to retrain workers for other industries.

The second position, which has been taken by Japan, Korea, Taiwan, and others, contests the link between subsidies and environmental damage, and instead asserts that inadequate fisheries management is the main cause of unsustainable fishing. ${ }^{83}$ These countries contend that subsidies are not dangerous to fishery resources if the fisheries regime is properly managed, and that reliance on the work of the fisheries management regimes is sufficient. In line with this approach, developing coastal states that oppose subsidies disciplines have argued that fisheries management issues are not an appropriate subject for the WTO and that other forums, such as the FAO, should address subsidies issues. ${ }^{84}$ The EC has also stated that other forums have priority over the WTO Rules Group. ${ }^{85}$

Although Japan, Korea, and Taiwan have accepted the jurisdiction of the WTO to deal with the issue ${ }^{86}$ they have maintained their emphasis on the non-WTO management of fisheries. ${ }^{87}$ As an alternative to the recommendation of a comprehensive ban put forward by the Friends of Fish, these WTO members advocate the general permissibility of fisheries subsidies with certain limited prohibitions. ${ }^{88}$ They propose that WTO members identify the subsidies that they deem illegal, such as capacity-enhancing and IUU-supporting subsidies, and allow all others. ${ }^{89}$ Japan has also proposed that certain subsidies for vessel construction be allowed if the fisheries are properly managed. ${ }^{90}$ This reliance on management has attracted strong criticism from other WTO members. ${ }^{91}$

Within both sets of positions, there is an underlying problem of how the WTO should differentiate between harmful subsidies and those subsidies that enhance sustainability of the fishing sector. There are no universal definitions; instead, much depends on the context in which the subsidies are provided and the underlying social and economic conditions. For example, a subsidy used to decommission an existing vessel, which may be 'good' to reduce overcapacity of one state, may be 'bad' if the vessel is made available to another overexploited fishery. There is

83 See, e.g., WTO Docs TN/RL/W/11, TN/RL/W/17, TN/RL/W/52, TN/RL/W/69, and TN/RL/W/97.

84 See, e.g., positions of Antigua and Barbuda, Barbados, Belize, Dominican Republic, Fiji, Grenada, Guyana, Jamaica, the Maldives, Papua New Guinea, St Kitts and Nevis, St Lucia, Solomon Islands, and Trinidad and Tobago, set out in WTO Docs TN/RL/W/136, TN/RL/GEN/57/Rev.2, esp para. 12. See also with respect to UNCLOS, claims made by WTO Doc TN/RL/W/136, p 2, reproduced by Roman Grynberg and Natallie Rochester, 'The Emerging Architecture of a World Trade Organization Fisheries Subsidies Agreement and the Interests of Developing Coastal States' (2005) 39 Journal of World Trade 503, 522.

85 WTO Doc TN/RL/W82, para. 5.

86 See Rules Group meeting of 28 November 2004, summarized in WTO Doc TN/RL/M/18.

87 WTO Doc TN/RL/W/164, para. 5-6.

88 See, e.g., WTO Doc TN/RL/W/159.

89 See, e.g., WTO Doc TN/RL/W/164 (Japan).

90 Ibid.

91 See WTO Doc TN/RL/M/18, see esp para. 6 ('One Participant noted that the sponsor's definition of a properly managed fishery covered most, if not all, of the 75 per cent of fisheries that were currently overexploited'). 
significant disagreement in particular about how the Rules Group, in framing and implementing the new rules, should rely on information and incorporate existing norms from other regimes. For example, is it relevant that there is not, and never can be, parallel membership between the WTO and other relevant regimes (in the sense that some WTO members, such as the Customs Territory of Taiwan, are ineligible to be members of the FAO)? Should this lack of uniformity of state membership lead WTO members to rely solely on their own fisheries and environmental ministries to coordinate information? What other models for learning and information-exchange, such as institutional observership or informal deliberation, can be used? What effect will such inter-regime collaboration have on the implementation of the disciplines and proposed use of standards, benchmarks, and peer review from the law of the sea and FAO ? Section 2 examines the challenges and opportunities of regime interaction in the WTO negotiations.

\section{The challenges and opportunities of regime interaction}

The challenges and opportunities of interaction by the WTO with other regimes in the fisheries subsidies negotiations can be divided into the need to learn about existing regimes, which arises largely, but not solely, at the negotiation stage, and the need to entrench inter-regime linkages in the proposed disciplines. Accordingly, the first sub-section examines learning and information exchange in the context of the Rules Group activities. It suggests that inter-regime learning is variously facilitated and constrained by legal assumptions that can be separated into three different models. The second sub-section then considers how the Chair's text incorporates standards, benchmarks, and peer review from the law of the sea and $\mathrm{FAO}$ regimes. This ongoing regime interaction is compared to existing rules in the SCM Agreement and the SPS and TBT Agreements, which allow for ongoing interaction between the WTO, the OECD, and a number of organizations involved in product standards. This comparative analysis informs the emphasis in Section 3 on inter-regime deliberation and scrutiny as safeguards against international law's fragmentation.

\section{Negotiations and inter-regime learning: three models}

Rules Group participants have learned about the law of the sea and FAO regimes in various ways. First, they have drawn upon their own national resources, for example by consulting with fisheries agencies and environmental ministries. Secondly, they have heard directly from intergovernmental organizations, such as the FAO. Thirdly, they have deliberated with stakeholders, ranging from industry organizations, other NGOs, other intergovernmental organizations, and other countries, within informal forums. These three modes of learning can be conceptualized as models that focus on learning and information exchange by: (1) state actors; (2) actors working within the international institutional framework, including secretariat staff; and (3) stakeholders affected by the rules. These three 
models, while at first glance apparently simplistic, follow common theoretical assumptions about the role of states within international law. The purpose of the models is therefore not to analyse the strategy of the negotiators, ${ }^{92}$ but to assess differing conceptions of regime interaction. These conceptions have major implications for international law's fragmentation and for the practical and effective operation of the resulting disciplines on fisheries subsidies.

\section{Self-contained regimes and national policy coordination}

The first model conceives of learning as driven by state actors within the international system. Such actors, in the context of the Doha Round, include customs territories that have WTO membership. According to this model, the trade delegations in the Rules Group seek to ascertain and represent the consolidated views of their respective states in crafting fisheries subsidies disciplines. Such views will, to varying degrees, include the perspectives of domestic stakeholders who will be affected by the trade rules, although this is a matter for individual WTO members. ${ }^{93}$

In the context of international law's fragmentation, the question arises as to how this model caters for global policy issues that involve several overlapping regimes. The immediate response is to emphasize the national policy coordination between domestic rule-making sectors. Trade ministries must coordinate with fisheries ministries, environmental ministries and other relevant departments in ways that are specific to the vagaries of each policy problem and the different structures and constitutions (federalist, unitary, etc) of each domestic legal system. Depending on whether the particular WTO member is a member of other intergovernmental organizations, such domestic national coordination may also draw on information and experience in other regimes. For example, some Rules Group participants have shown initiative in reporting on their relevant experience in other organizations. This information has influenced proposals, written and oral replies, and even negotiation strategy. ${ }^{94}$

This conception is apparently consistent with the findings of the ILC Study Group, in that it focuses on the need for the consent of the primary actors of international law, namely states, in resolving issues of fragmentation. It also resonates with traditional accounts of 'state sovereignty' in international law that emphasize the state as the supreme authority, and claim that, although states are bound by the general system of international law, they are not subject to specific

92 See, e.g., applications of game theory in Howard Raiffa, John Richardson, and David Metcalfe, Negotiation Analysis: The Science and Art of Collaborative Decision Making (2003).

93 See, e.g., Brian Hocking, "Changing the Terms of Trade Policy Making: From the "Club" to the “Multistakeholder” Model' (2004) 3 World Trade Review 3 (considering domestic participatory models in the context of the EU and Canada). Cf. suggestions of problems in enhancing participation of domestic constituents by Valentin Zahrnt, 'Domestic Constituents and the Formulation of WTO Negotiating Positions: What the Delegates Say' (2008) 7 World Trade Review 393.

94 See, e.g., Korea reminded the Rules Group that OECD negotiations to discipline steel subsidies had failed because OECD participants were not able to agree on exceptions: (2004) 8:38 Bridges Weekly Trade News Digest 3. 
international laws except by their consent. ${ }^{95}$ This perspective is often heard in the trade regime through the mantra that the WTO is a 'member-driven organization'.

There are extreme versions of the attempt by states to monopolize the influences of particular regimes. For example, the Doha negotiations on the relationship between WTO rules and specific trade obligations in certain multilateral environment agreements (MEAs) are expressly limited to WTO members that are already parties to the relevant MEAs. ${ }^{96}$ As such, WTO members have agreed to negotiate on the boundaries between trade and other regimes, but only for situations where WTO members have already consented to the other regimes ('parallel membership'). In consequence, there is an express refusal to consider regime interaction that occurs in situations where there is not uniform membership between the WTO and other regimes. This perspective is echoed in some WTO cases, such as the Biotech panel's restrictive mode of treaty-interpretation. ${ }^{97}$

These extreme attitudes lead to the view that the WTO operates as a 'selfcontained regime'. ${ }^{98}$ This view is logically unsustainable, however, when one considers that international regimes 'are always situated in a systemic environment'. ${ }^{99}$ Moreover, the view is inconsistent with WTO jurisprudence that trade law should not be read 'in clinical isolation from public international law' ${ }^{100}$ Practically, too, the extreme ideal of parallel membership is bound to fail. There is no parallel membership between the WTO and any of the relevant intergovernmental organizations dealing with fisheries. ${ }^{101}$ For example, Singapore, Brunei Darussalam, and the member custom territories are not members of the FAO (and conversely there are several FAO members that are not WTO members). In addition, organizations such as the OECD have exclusive membership and are closed to many WTO members.

In addition to flaws in the notion of parallel membership for regime interaction, a sole reliance on national policy coordination for effective international fisheries

95 An extreme formulation of this principle is contained in the Case of the S.S. 'Lotus' (France and Turkey), where the Permanent Court of International Justice stated that '[r]estrictions upon the independence of States cannot therefore be presumed': (1927) PCIJ, Ser. A., No. 10, 18. Note also the principle that a treaty does not create either obligations or rights for a third State without its consent: VCLT Art. 34 (pacta tertiis).

96 Doha Declaration, above n 75, para. 31(i).

97 The panel found that various environmental treaty obligations could not constitute context for the interpretation of WTO obligations according to the VCLT Art. 31(3)(c) because they had not been agreed by the entire WTO membership: see further Margaret Young, 'The WTO's Use of Relevant Rules of International Law: An Analysis of the Biotech Case' (2007) 56 International and Comparative Law Quarterly 907.

98 This extreme view was criticized by the ILC Analytical Study, above n 14, para. 450 (227); see further Anja Lindroos and Michael Mehling, "Dispelling the Chimera of "Self-Contained Regimes": International Law and the WTO’ (2006) 16 European Journal of International Law 857.

99 ILC Analytical Study, above n 14, para. 179 (94).

100 Appellate Body Report, United States - Standards for Reformulated and Conventional Gasoline (US-Gasoline) WT/DS2/AB/R 17 (circulated 20 May 1996).

101 These would include the FAO, UNEP, the OECD, the World Bank and treaties such as CITES and the Convention on Biological Diversity. 
governance is insufficient. There are major deficiencies in domestic policy coordination in the fisheries context. ${ }^{102}$ Perhaps because of the relative unimportance of fisheries issues on some national policy agendas, there are failures in coordinating national information and positions, leading to diverging state positions within different international regimes. Moreover, there is a practical need in the fisheries context for information and expertise on global, as well as intra-state, behaviour. Given that failures in achieving fisheries sustainability often occur because of insufficient restraint by a multitude of states, an overarching perspective on fisheries is needed, rather than a reliance on individual accounts from WTO members themselves. Such a perspective exists in the context of rules and data developed in other international regimes, including within organizations like the FAO. The next sub-section thus considers how representative organizations interact for interregime learning.

\section{Interaction by intergovernmental organizations}

A second model of information sharing acknowledges the role of international organizations in inter-regime learning to assist in the crafting of rules on fisheries subsidies. Such coordination between international organizations has long been regarded as essential in combating problems of legal fragmentation. ${ }^{103}$ Links between organizations may also counter alleged biases or 'insensitivities' against ecological issues within the trade regime. ${ }^{104}$

WTO members have endorsed this model of institutional interaction in certain contexts. WTO members, meeting through the General Council, are responsible for making 'appropriate arrangements' for effective cooperation and consultation with intergovernmental organizations and NGOs. ${ }^{105}$ The General Council has entered into several cooperative agreements ${ }^{106}$ and has allowed certain organizations to observe some proceedings of WTO committees. Observership is to be considered by the respective WTO committee on a case-by-case basis, taking account of factors such as the nature of the work of the organization, its membership (including the number of WTO members who are members of the other

102 Noted, e.g., in high-level UN consultations for improving general ocean governance: UN Doc A/55/274, Annex I, para. 15.

103 For a timely account, see C W Jenks, 'Coordination in International Organization: An Introductory Survey’ (1951) 28 British Year Book of International Law 29.

104 See Oren Perez, Ecological Sensitivity and Global Legal Pluralism: Rethinking the Trade and Environment Debate (2004), 262 (advocating links between the WTO, organizations such as UNEP and NGOs, amongst a number of policy prescriptions).

105 Marrakesh Agreement Art. V. Art. V has been considered as evidence that the WTO 'has treatymaking power and that in principle the General Council exercises it': Pieter Jan Kuijper, 'Some Institutional Issues Presented before the WTO', in Daniel Kennedy and James Southwick (eds.), The Political Economy of International Trade Law: Essays in Honour of Robert E Hudec (2002) 81, 108.

106 For example, with the UN, WIPO, the World Bank, the IMF, and the World Organization for Animal Health (OIE). See also cooperative agreements concluded by the WTO Secretariat itself, such as with UNEP: Cooperation between the WTO and UNEP Secretariats, Press Release Press/154 (29 November 1999). 
organization), and reciprocity of access. ${ }^{107}$ The General Council has also established guidelines for cooperation with NGOs. ${ }^{108}$

In the Committee on Trade and Environment, where fisheries subsidies were first discussed, a number of international organizations, whose membership and objectives vary from the WTO, ${ }^{109}$ have rights to observe proceedings. Organizations such as the FAO have directly reported on fisheries issues. Indeed, commentators have considered that the attendance by FAO representatives at CTE meetings influenced states' commitment to fisheries subsidies reform. ${ }^{110}$

At the beginning of the Rules Group negotiations, the need for participants to learn from relevant intergovernmental organizations and NGOs was identified. The United States, for example, urged the Rules Group to 'explore ways to draw upon information from other organizations', including the FAO, RFMOs, and non-governmental groups and individuals. ${ }^{111}$ The Chair of the Rules Group engaged in informal consultations on whether to extend observership to external participants. ${ }^{112}$ However, proposals to 'enrich' the Rules Group in this way were met with criticisms from some members. ${ }^{113}$ Perhaps the political contentiousness of the Rules Group negotiating agenda, which ranges from fisheries subsidies to more general subsidies and anti-dumping reform, led to a perception of possible 'capture' by special interests among the protectionist industries affected by antidumping reform. ${ }^{114}$ The question of observers disappeared from the Rules Group agenda in early 2005, and the status quo of closed access remained.

The Rules Group's formal procedures for participation and observership can be contrasted to professed optimism by the WTO Secretariat about working with other intergovernmental organizations in the framing of the fisheries subsidies rules. Director-General Lamy, for example, claims that cooperation between the WTO and other organizations 'depends very largely on goodwill and a common sense of problem solving rather than strict mandates'. ${ }^{115}$ Given the restrictions on formal interaction between the Rules Group, intergovernmental organizations,

107 General Council, 'Rules of Procedure for Meetings of the General Council', WT/L/161 (25 July 1996), Rule 11 and Annex 3. The criteria for the granting of observer status are the subject of Doha negotiations in the Special Session of the CTE: see Doha Declaration, above n 75, para. 31(ii).

108 WTO General Council, 'Guidelines for Arrangements on Relations with Non-Governmental Organizations', adopted on 18 July 1996 (WT/L/162).

109 For list of observers to CTE, see WTO Doc WT/CTE/INF/6/Rev.4.

110 Olav Schram Stokke and Clare Coffey, 'Institutional Interplay and Responsible Fisheries: Combating Subsidies, Developing Precaution', in Sebastian Oberthür and Thomas Gehring, Institutional Interaction in Global Environmental Governance (MIT Press, 2006) 127, 136. The existence of the FAO IPOA on Capacity was communicated formally to the CTE in 1999: WT/CTE/W/126.

111 WTO Doc TN/RL/W/77, para. 8.

112 WTO Doc TN/RL/M/1; see also TN/RL/1.

113 WTO Doc TN/RL/M/7.

114 But compare the extremely sensitive Doha negotiating groups on agriculture and services, which extend observer status to the IGOs that already participated in the work of the regular committees. This comparison has been made by several members: see WTO Doc TN/TE/R/4, see para. 115 .

115 Consultation by author with Director-General Lamy during online chat discussion hosted by www.wto.org, 16 November 2007. ('The WTO today, and the GATT for 50 years before it, has always 
and NGOs, it would seem that inter-regime learning must occur in alternative, informal settings. The next section considers a third model of information sharing where knowledge production about subsidies and sustainability allows stakeholders, including WTO members, to deliberate upon fisheries subsidies issues outside of the institutional strictures of the Rules Group.

\section{Deliberation by affected actors}

Learning and information sharing across regimes may occur outside of the formal structures established by WTO members, and instead through open deliberation by a range of actors who will be affected by the rules. These 'stakeholders' include environmental NGOs, fishing organizations and epistemic communities of experts, as well as states and intergovernmental organizations. Many of these groups and networks do not have the 'representative' functions of states in international law. ${ }^{116}$

In contrast to formal restrictions within the Rules Group, there are several examples in the fisheries subsidies negotiations of intergovernmental organizations and NGOs promoting deliberation through informal institutional linkages, reporting, and information sharing. The WTO Secretariat has led some of these initiatives. For example, the WTO Secretariat has organized special symposia as part of the quest for synergies between trade and environment, ${ }^{117}$ and has conducted regional seminars for members with the participation of international organizations. ${ }^{118}$ Officials from the WTO have attended FAO expert consultations and meetings. ${ }^{119}$ The WTO Secretariat has issued reports on the activities of intergovernmental organizations and NGOs, mainly in servicing the CTE discussions, ${ }^{120}$ but also for the Rules Group. ${ }^{121}$ There is also coordination between the CTE and the Rules Group. ${ }^{122}$ More recently, representatives from the FAO secretariat have attended Rules Group negotiations in an informal capacity. ${ }^{123}$

had a smaller membership than most other IGOs, but that has never stopped us from working closely with them.')

116 On the growth of networks of bureaucrats and elites with purported representative functions, see Anne-Marie Slaughter, A New World Order (Princeton University Press, 2005); on rise of advocacy networks, see e.g. Margaret E Keck and Kathryn Sikkink, Activists Beyond Borders: Advocacy Networks in International Politics (1998).

117 See, e.g., 'WTO Symposium on Trade and Sustainable Development within the Framework of Paragraph 51 of the Doha Ministerial Declaration' on 10-11 October 2005, which included panellists from the FAO, UNEP and a developing country NGO: see http://www.wto.org/english/tratop_e/envir_e/ sym_oct05_e/sym_oct05_e.htm\#part2 (last accessed 4 December 2008).

118 See, e.g., WTO Doc WT/CTE/W/216.

119 WTO Doc WT/CTE/W/189; See also the 'side-event' of the FAO Sub-Committee on Fish Trade, Bremen, 2-6 June 2008.

120 See, e.g., WTO Doc WT/CTE/W/167/Add.1 (reviewing activities of APEC, FAO, OECD, UNEP as well as WWF and ICTSD).

121 See, e.g., WTO Doc TN/RL/W/197.

122 See, e.g., attendance by Director of the Rules Division to CTE: WTO Doc WT/CTE/GEN/10.

123 Interview by author with staff member of the Food and Agriculture Organization (Rome, 2 July 2008). 
The WTO Secretariat website facilitates this deliberation to some degree. ${ }^{124}$ Most importantly, the website disseminates the results of the Rules Group negotiations. Thus, although the Rules Group is formally closed, there is scope for external participants to access its decision making because country submissions are mostly posted online. ${ }^{125}$ Secretariat summaries of Rules Group meetings are also made public, although they are usually limited in detail and there is sometimes a delay of several months between meeting and publication. Reporting by other organizations suggests, however, that the Secretariat responds to requests for general information and briefings. ${ }^{126}$ In addition, the website includes a portal for non-state submissions, which are accessible for members as well as the general public, although the papers are not systematically catalogued. ${ }^{127}$

Outside of the WTO, other opportunities for informal information sharing and learning have emerged. Organizations such as UNEP, ${ }^{128} \mathrm{WWF}^{129}$ and ICSTD ${ }^{130}$ have offered a series of workshops. ${ }^{131}$ Stakeholders from national governments (including officials from environment, trade, and fisheries agencies), intergovernmental organizations, RFMOs, NGOs, and academic institutions have participated. Such consultations are often timed to coincide with closed sessions of the Rules Group. ${ }^{132}$

Rather than striving for consensus, the workshops have encouraged open experimentation and learning. In addition to information about subsidy effects and fisheries issues, the workshops have provided information on the laws and standards that operate within other international regimes. ${ }^{133}$ For example, participants have discussed the relative breadth of acceptance of particular norms, such as the near universal application of the FAO Code of Conduct as compared to the very limited enforcement of the FAO IPOA-Capacity. This has allowed WTO members to learn about and interrogate intergovernmental organizations and standards that

124 The website is part of the WTO's outreach promoted by its guidelines on NGOs, above $\mathrm{n} 108$; see www.wto.org/english/forums_e/ngo_e/ngo_e.htm (last accessed 4 December 2008).

$125 \mathrm{Cf}$. Informal country ('job') submissions, which are internal and not available.

126 This is in keeping with the General Council's commitment to enhancing contacts with NGOs and other organizations through secretariat consultations: See its guidelines on NGOs, above n 108.

127 The NGO portal includes papers on fisheries subsidies submitted to the WTO by a range of NGOs, from a little-known Filipino development NGO to Greenpeace International.

128 The United Nations Environment Program has a stated strategy to ensure national coordination between trade, environment and sectoral ministries: see World Summit Plan of Implementation (2002), above n 61, paras, 97(c), 154; see also the work of the Economics and Trade Branch (UNEP-ETB), part of the UNEP Division of Technology, Industry and Economics, at http://www.unep.ch/etb/about/index.php (accessed 30 January 2006).

129 World Wide Fund for Nature: see http://www.wwf.org/.

130 International Centre for Trade and Sustainable Development: see http://ictsd.net/.

131 See, e.g., http://www.unep.ch/etb/events/2007fish_symposium.php (last accessed 4 December 2008). See also workshop organized by UNEP, WWF, Oceana, and ICTSD after the circulation of the draft Chair's text in November 2007.

132 See, e.g., reported at (2006) 10:10 Bridges Weekly Trade News Digest 5.

133 See, e.g., David Schorr and John Caddy, Sustainability Criteria for Fisheries Subsidies: Options for the WTO and Beyond (Commissioned by UNEP and WWF) (2007). 
may be relevant to the proposed disciplines. Written conclusions from the workshops, which tend to demonstrate plurality of perspectives rather than agreement, are distributed directly to Rules Group participants by certain WTO members ${ }^{134}$ and are publicly disseminated via the UNEP and WWF websites.

The influence of informal deliberation by stakeholders in the fisheries subsidies negotiations is difficult to prove empirically. According to interviews with trade delegates, WTO secretariat staff, and FAO representatives, the informal consultations have been regarded as extremely useful opportunities for learning about fisheries subsidies issues. ${ }^{135}$ In addition, an analysis of the written Rules Group submissions reveals a strong influence. Some of the proposals have closely followed the positions of external stakeholders, such as the WWF. ${ }^{136}$ This is reflected in comments by the WTO Secretariat itself, which acknowledge that NGOs can influence the negotiating positions of Rules Group participants. ${ }^{137}$ Indeed, the Director-General has attributed the inclusion of fisheries subsidies in the Doha agenda to the influence of civil society. ${ }^{138}$

The activities described above suggest that a community of stakeholders has addressed fisheries subsidies issues at the WTO notwithstanding that they have been denied formal rights to participate and observe negotiations in the Rules Group. Interdisciplinary workshops and informal links between secretariats and other groups are spatially and temporally linked to the Rules Group negotiations and have had a material influence on proposals. The remainder of this section examines the proposed text of the subsidy disciplines and speculates upon the influence of stakeholder deliberation on the ongoing implementation of the rules, and in particular on the proposed collaboration between the WTO and other organizations. Section 3 then examines the normative and institutional impact of stakeholder deliberation on WTO rule making in the theoretical context of a fragmented legal order.

\section{Inter-regime links in the proposed rules: three examples}

The proposed WTO rules, as currently contained in the Chair's text, ${ }^{139}$ incorporate norms from other regimes and entrench collaborative procedures in three main areas: (1) the classification of subsidies; (2) the benchmarks for fisheries

134 See, e.g., formal submission by New Zealand in WTO Doc TN/RL/W/207.

135 Interview by author with staff member of the WTO Secretariat (Geneva, 24 August 2005); interview by author with staff member of the Food and Agriculture Organization (Rome, 2 July 2008).

136 See, e.g., Brazil's concept of 'patently at risk' fishery in WTO Doc TN/RL/GEN/79/R3 as similar to the WWF position paper noted above $\mathrm{n} 68,130$.

137 See, e.g., comment of Director of the Rules Division about the impact of environmental NGOs on the subsidies negotiations in WTO Doc WT/CTE/GEN/10. ('Over time, these views from civil society may eventually find their way into the negotiating positions of certain participants.')

138 Pascal Lamy, 'Civil Society is Influencing the WTO Agenda' Keynote address to the WTO Public Forum on 4 October 2007: see http://www.wto.org/english/news_e/sppl_e/sppl73_e.htm (last accessed 20 March 2008).

139 Chair's text, above n 78 . 
management to which WTO members must adhere; and (3) the settlement of subsidy disputes. This is not the first time that WTO members have crafted rules that require ongoing interaction or collaboration with non-WTO regimes, and this subsection examines the proposals for fisheries subsidy disciplines in the context of practice resulting from other parts of the SCM Agreement and the SBS and TBT Agreements.

\section{Classifying 'good' and 'bad' subsidies through fisheries standards}

The Chair's text contains a list of negotiated prohibited subsidies ('red box') as well as exempted subsidies ('green box'). The provisions utilize existing fisheries data, norms, and institutions in a variety of ways to classify fisheries subsidies.

One method is to expressly adopt an FAO standard. The proposed red box includes a prohibition on 'subsidies the benefits of which are conferred on any vessel engaged in illegal, unreported or unregulated fishing'. ${ }^{140}$ The provision directly incorporates the definition of IUU fishing from the FAO's international plan of action. ${ }^{141}$ According to this definition, illegal fishing includes fishing by vessels flying the flag of states that are parties to a relevant RFMO, but that 'operate in contravention of the conservation and management measures adopted by [the $\mathrm{RFMO}$ ] and by which the states are bound, or relevant provisions of the applicable international law'. As a consequence, the implementation of the WTO subsidy rules depends upon an assessment of WTO members' compliance with relevant rules of an RFMO or other applicable international law.

WTO lawyers will be familiar with this form of express reference to other regimes in the classification of WTO-consistent behaviour. For example, the SPS and TBT Agreement rely on international standard-setting bodies to determine whether WTO members can be exempt from disciplines because their trade measures are 'necessary' for a legitimate domestic objective. According to the SPS Agreement, WTO members' measures are presumed to be 'necessary' if they conform to international standards promulgated by listed groups, such as the Codex Alimentarius Commission, or are preceded by proven scientific risk assessments. ${ }^{142}$ According to the TBT Agreement, members' measures are presumed to be exempt from disciplines if they are 'in accordance' with international standards set by an open list of international standard-setting bodies. ${ }^{143}$

The reference to international standards in the TBT and SPS Agreements has led to a number of criticisms. The standards may have a determinative role in WTO

140 Ibid., Article I.1(h), footnote 81. (The terms 'illegal fishing', 'unreported fishing', and 'unregulated fishing' shall have the same meaning as in para. 3 of the 'International Plan of Action to Prevent, Deter and Eliminate Illegal Unreported and Unregulated Fishing of the [FAO]'.)

141 See above $\mathrm{n} 54$ and accompanying text.

142 SPS Agreement, Art. 3.2.

143 TBT Agreement, Art. 2. 
disputes, even if they were not intended to be binding in forums such as Codex. ${ }^{144}$ This problem is exacerbated if a standard has been agreed without consensus between relevant participants in the standard-setting process. ${ }^{145}$ As such, a WTO member may be required to be in conformity with a particular standard, even if it voted against the adoption of the standard in the relevant forum and even if the standard is not binding in that forum. ${ }^{146}$

By contrast, an alternative method of subsidy classification has been proposed by the EC, possibly because as a respondent in much of the relevant case law it is particularly sensitive to the potential application of standards from other international regimes. Suspicious of referring expressly to the law of the sea and FAO regimes in the proposed subsidy disciplines, it has proposed a catch-all prohibition which would prohibit subsidies where the benefits 'are conferred on any fishing vessel or fishing activity affecting fish stocks that are in an unequivocally overfished condition'. ${ }^{147}$ The italicized phrase does not refer to any other international regimes. Yet this form has been heavily criticized by other WTO members, who have expressed concern that the 'unequivocally overfished' condition is too vague and obscure, and leaves an adjudicating body with too little guidance and too much discretion in interpreting the term. ${ }^{148}$

A third method of standard setting appears in the proposed 'green box' exemptions, which refer to international fisheries management regimes, systems, and programs. The Chair's text exempts a range of subsidies, including those used for: (1) compliance with 'fisheries management regimes aimed at sustainable use and conservation'; $;^{149}(2)$ vessel decommissioning or capacity reduction programmes provided that fisheries management systems are in place; ${ }^{150}$ and (3) 'special and differential treatment' provisions for developing countries. ${ }^{151}$

144 See esp TBT Agreement, Art. 2.4; Appellate Body Report, European Communities - Trade Description of Sardines (WT/DS231/AB/R) (circulated 26 September 2002).

145 The Codex, OIE and IPPC have historically adopted standards by consensus, with some notable and controversial exceptions: see further Doaa Abdel Motaal, "The "Multilateral Scientific Consensus" and the World Trade Organization' (2004) 38 Journal of World Trade 855.

146 See Appellate Body Report, European Communities - Trade Description of Sardines (WT/DS231/ $\mathrm{AB} / \mathrm{R}$ ) (circulated 26 September 2002), para. 225 (relating to a Codex standard for the description of 'sardines'); see also Appellate Body Report, European Communities-Measures Concerning Meat and Meat Products (Hormones) WT/DS26/AB/R (circulated 16 January 1998) (relating to a Codex hormonetreated beef standard, which had been adopted by secret vote given the lack of agreement between the United States and the European Union).

147 Chair's text, above n 79, Art. I.2. (my emphasis).

148 (2007) 11 : 44 Bridges Weekly Trade News Digest. Similarly, the Chair's text grants an exemption for otherwise prohibited subsidies that benefit vessel construction and operating costs 'in the exceptional case of natural disaster relief' (Art. I.1). This exemption is limited to a point in time at which fishing capacity is restored and 'sustainable'. This point in time is to be 'established through a science-based assessment of the post-disaster status of the fishery' (footnote 77 to Art. I.1).

149 Chair's text, above n 78, Art. II(b)(3).

150 Ibid., Art. II(d)(4).

151 Ibid., Art. III. 
The special and differential treatment builds on earlier proposals that sought to rely on non-WTO regimes to ensure that exempted subsidies maintained standards of sustainability. For example, Brazil initially proposed to allow developing countries that were part of an RFMO to grant capacity-enhancing subsidies, as long as the developing country's fishing capacity did not exceed the sustainable level of exploitation as defined by the particular RFMO. ${ }^{152}$ Argentina initially proposed that developing countries wishing to qualify for special and differential treatment should implement national fisheries management systems 'in keeping' with the FAO Code of Conduct. ${ }^{153}$ The European Union, on the other hand, sought to contain the issue of sustainable special and differential treatment entirely within the WTO. It proposed that developing countries be exempted from subsidy disciplines as long as their fishing capacity did not increase to an extent that it presented an 'impediment to the sustainable exploitation of fishery resources worldwide'. ${ }^{154}$

Instead, the Chair's text provides that developing countries may subsidize vessel construction, but only if the vessels are used within the member's relevant EEZ, if the fish stocks within that EEZ have been scientifically assessed 'in accordance with relevant international standards', and if the stock assessment has been subject to peer review by the FAO. ${ }^{155}$ In addition, international organizations such as the FAO are to provide technical assistance to developing countries. ${ }^{156}$ The final overarching safeguard to ensure that special and differential treatment and other exempted subsidies do not lead to overfishing is contained in the condition that any member seeking an exemption 'shall operate a fisheries management system ... designed to prevent overfishing'. ${ }^{157}$

The conditionality regarding management systems is more fully described in the next subsection, but there are two remaining points to note about the proposed use of standards. The Chair's text does not endorse all standards of fisheries regimes. For example, the Chair's text rejects the major jurisdictional concept of these regimes: by attributing subsidies to members regardless of vessel flags or the application of rules of origin to the fish involved, ${ }^{158}$ the text purposively avoids enduring problems of 'flag' jurisdiction in the law of the sea, as well as difficulties in assessing the origin of fish products. ${ }^{159}$ This decision may well have been made after trade delegates learned from the experiences of fisheries delegates, international organizations, and NGOs, as described

152 WTO Doc TN/RL/GEN/79 (see proposed Art. 6).

153 WTO Doc TN/RL/GEN/138 (see proposed Art. X.3).

154 WTO Doc TN/RL/GEN/134 (see proposed Art. 6.1).

155 Chair's text, above n 78, Art. III.2(b)(3).

156 Ibid., Art. III.4; see further clarification by Chair Valles Galmes noted above n 79.

157 Ibid., Art. V.1.

158 Ibid., Art. IV.2.

159 On problems of rules of origin in the fisheries context, see, e.g., Roman Grynberg and Natallie Rochester, 'Expert Opinion: Fixing Cotonou's Rules of Origin Regime', in Adil Najam, Mark Halle, and Ricardo Meléndez-Ortiz (eds.), Trade and Environment: A Resource Book (2007) 107. 
according to the third model of learning outlined above. ${ }^{160}$ The other point to note is that the use of fisheries standards brings a different rationale to the WTO subsidies disciplines, which have been critiqued as economically irrational and incoherent. ${ }^{161}$ The proposed approach focuses disciplines on subsidies that are harmful to the achievement of agreed global goods (albeit that such agreement occurs in non-WTO forums).

\section{Conditionality through benchmarking and peer review}

To safeguard fisheries sustainability, the Chair's text proposes an overarching condition that all WTO members seeking exemptions for their subsidy practices operate a particular kind of fisheries management system. ${ }^{162}$ These management systems are to be based on 'internationally-recognized best practices for fisheries management and conservation' and are to include regular science-based stock assessments and capacity and management measures. Such best practices are said to be reflected in a non-exhaustive list of five international instruments: (1) the Fish Stocks Agreement; (2) the Code of Conduct; (3) the Compliance Agreement; (4) technical guidelines; and (5) plans of action. ${ }^{163}$ Accordingly, instruments developed within the law of the sea and the FAO regime will have a contingent role in the WTO subsidies regime.

This group of five fisheries instruments is relevant to other proposed exemptions and in the assessment of actionable subsidies. Subsidies relating to the procurement of access rights to foreign fisheries in developing country WTO members are not prohibited provided that the terms of access include provisions designed to prevent overfishing 'based on internationally-recognized best practices ... as reflected in' this group of five fisheries instruments. ${ }^{164}$ The 'amber-box' test for actionable subsidies, which may be subject to member complaints based on their adverse effects, ${ }^{165}$ also refers to the group of five fisheries instruments as relevant evidence. Information about the subsidizing member's implementation of 'internationally-recognized best practices for fisheries management and conservation' will assist in establishing whether a member is causing, through the use of a subsidy, depletion of straddling or migratory fish stocks or stocks in which another WTO member has identifiable fishing interests.

One of the difficulties of using these five instruments as benchmarks is the potential for WTO members to adopt management systems on paper without

160 Notwithstanding that such a link is difficult to prove empirically: see above $\mathrm{n} 135$ and surrounding text.

161 See, e.g., Kyle Bagwell, Petros Mavroidis, and Robert Staiger, 'It's a Question of Market Access' (2002) 96 American Journal of International Law 56.

162 Chair's text, above n 78, Art. V.1.

163 Ibid., Art. V.

164 Ibid., Art. III.3.

165 Ibid., Art. IV. See further Marc Benitah, 'Five Suggestions for Clarifying the Draft Text on Fisheries Subsidies' (2008) 12:1 Bridges Trade and Biological Resources News Digest 21, 22. 
adequately implementing or enforcing them. To address this, the Chair's text requires members to 'adopt and implement' domestic legislation and judicial enforcement mechanisms with full transparency. Information about these and other aspects of the fisheries management system is to be made publicly accessible and subject to peer review.

Review of WTO members' fisheries management systems takes place in three ways. First, members are to notify the existence and operation of their fisheries management systems, including the results of stock assessments, to the FAO. ${ }^{166}$ The FAO will determine the specific information it requires and then subject the management system to peer review before the subsidy is granted. The Chair's text recognizes that not all WTO members are members of the FAO. In that event, it provides that the relevant WTO member's fisheries management information shall be notified to 'another relevant international organization'. ${ }^{167}$ Secondly, information about the fisheries management system, including the outcome of the FAO peer review, is to be notified to the SCM Committee, ${ }^{168}$ an internal committee made up of member representatives that currently reviews subsidy notifications. ${ }^{169}$ Thirdly, WTO members are to maintain a domestic 'enquiry point', to which WTO members and other interested parties may direct their scientific or trade questions. ${ }^{170}$

The role of the FAO as a peer reviewer of relevant aspects of WTO members' fisheries management systems appears to be a useful harnessing of the FAO's expertise, particularly on stock assessments. There is some evidence that the FAO was involved in the inclusion of this role in the Chair's text, ${ }^{171}$ suggesting that the regime interaction in the framing of the rules had a substantive effect on the development of ongoing interaction in the rules' implementation. However, some WTO members have expressed suspicion about the proposed collaboration between the WTO and other regimes. Taiwan, which is not a member of the UN, apparently objects to the involvement of an international organization to which not all WTO members belong. Norway, supported by some developing country members, would delete the peer review function and require simple notifications to the FAO or other relevant organizations. ${ }^{172}$ Other WTO members have noted their 'systemic concerns' with another intergovernmental

166 Ibid., Art. V.1.

167 Ibid., Art. V.1, footnote 86.

168 Ibid., Art. V.1; VI.4.

169 SCM Agreement Art. 24.

170 Chair's text, above n 78, Art. V.2. The enquiry point arrangement may have implications for the future allocation of the burden of proof for disputes: see EC-Sardines and commentary in Robert Howse, 'The Sardines Panel and AB Rulings - Some Preliminary Reactions' (2002) 29(3) Legal Issues of Economic Integration 247, 254; see also Henrik Horn and Joseph Weiler, 'European Communities - Trade Description of Sardines: Textualism and Its Discontent', in Henrik Horn and Petros Mavroidis (eds.), The WTO Case Law of 2002 (2003) 248, 275.

171 (2008) $12: 4$ Bridges Weekly Trade News Digest 5.

172 (2008) 12:11 Bridges Weekly Trade News Digest 6. 
organization 'passing judgment' on the adequacy of WTO members' management systems. ${ }^{173}$

In response to these concerns, the Chair of the Rules Group has emphasized the continuing role of the SCM Committee in maintaining a dialogue with the FAO, and proposed that the peer review process be considered as similar to the existing Trade Policy Review Mechanism (TPRM) ${ }^{174}$ The Chair's emphasis on the continuing role of the SCM Committee in maintaining an inter-regime dialogue can be compared to a set of existing and potential arrangements with another rather controversial intergovernmental organization: the OECD.

The OECD has a special role in the granting of existing exemptions for export subsidies that are otherwise prohibited. The SCM Agreement exempts export subsidies for certain export credit practices, if they are in conformity with provisions of a certain undertaking or 'successor undertaking' on official export credits. ${ }^{175}$ The infamous Annex $\mathrm{I}(\mathrm{k})$ provision refers to an arrangement concluded in the OECD in 1978 and revised most recently in $2008 .{ }^{176}$ The arrangement is selfdefined as a 'Gentlemen's Agreement among the Participants'. ${ }^{177}$ Current participants are Australia, Canada, the EC, Japan, Korea, New Zealand, Norway, Switzerland, and the United States. Other OECD members and non-members may be invited to become participants by the current participants. ${ }^{178}$

The term 'successor undertaking' allows the participants of the OECD Export Credit Arrangement to continually update the terms of the exemption as it applies to themselves and to the rest of the WTO membership. In the face of a challenge that it was unreasonable for a subgroup of WTO members to 'perpetually legislate on behalf of the overwhelming majority of the membership' in this way, ${ }^{179}$ a WTO panel has considered that such a delegation is justifiable in order to share necessary expertise. ${ }^{180}$ The Panel noted, however, that if the participants to the OECD Export Credit Arrangement 'were to abuse their power to modify the scope of the

173 WTO Doc TN/RL/W/232 (Annex C - Fisheries Subsidies), C-60.

174 (2008) 12:11 Bridges Weekly Trade News Digest 6. In the TPRM process, the WTO member under review produces a domestic trade policy report, which is then reviewed by the WTO Secretariat, which creates its own independent report. The General Council of the WTO (acting as a 'Trade Policy Review Body') then scrutinizes both reports with a view to enabling 'regular collective appreciation and evaluation' of the member's domestic trade policies: see Annex 3 of the Marrakesh Agreement Establishing the World Trade Organization 1994, especially para. C.

175 SCM Agreement, Art. 3.1(a) footnote 5; Annex I (k). For a detailed description of its operation, see Janet Koven Levit, 'A Bottom-Up Approach to International Lawmaking: The Tale of Three Trade Finance Instruments’ (2005) 30 Yale Journal of International Law 125, 157-167.

176 OECD, ‘Arrangement on Officially Supported Export Credits' (2008 revision): See OECD Trade and Agriculture Directorate TAD/PG(2007)28/FINAL. http://www.oecd.org/.

177 Ibid., Art. 2. (Surprisingly, the revisions have not amended this rather outdated expression.)

178 Ibid., Art. 10.

179 Panel Report, Brazil - Export Financing Programme for Aircraft WT/DS46/R (circulated 14 April 1999), para. 5.84. Brazil had separately complained that developing countries 'are not members of the OECD. They have no voice in the OECD': see para. 4.98.

180 Ibid., para. 5.88. 
safe haven, the recourse of other WTO members would be to renegotiate' the relevant provision of the SCM Agreement. ${ }^{181}$

Indeed, the Rules Group has since examined the operation of the exemption for official export credit practices, as part of its mandate for general subsidies reform. ${ }^{182}$ The Chair's text contains a proposal that the undertaking be notified to the SCM Committee. ${ }^{183}$ It further stipulates that the SCM Committee shall examine the notified undertaking on the request of a WTO member. This role will add to existing institutional arrangements, whereby the WTO Secretariat has observer status in the OECD export credit group, the OECD Secretariat has observer status within the SCM Committee, and panels may seek information during disputes. ${ }^{184}$

The existing and proposed collaborative practices of the WTO and OECD secretariats change the position of the OECD Export Credit Arrangement as a benchmark of conduct in the SCM Agreement. These practices require a level of transparency and openness in the OECD procedures to frame and update the benchmark, as scrutinized by SCM Committee. A similar development has occurred in the context of the TBT and SPS Agreements, probably as a response to the perceived problems in the interpretation of standards by adjudicating bodies. ${ }^{185}$ The TBT Committee, for example, has encouraged standard-setting bodies to operate with open, impartial, and transparent procedures. ${ }^{186}$ The SPS Committee has adopted a peer review role of member activities, ${ }^{187}$ while the WTO Secretariat, seeking to address deficiencies in compliance with SPS notification obligations, has conducted workshops on transparency and created an on-line searchable database. ${ }^{188}$

181 Ibid., para. 5.89, footnote 86 .

182 The Rules Group negotiates on fisheries subsidies, general subsidies reform and anti-dumping issues: see above $\mathrm{n} 75$ and accompanying text.

183 Draft Consolidated Chair Texts of the AD and SCM Agreements, WTO Doc TN/RL/W/213 (31 November 2007), 76 (amendment to Annex I (k)).

184 I note, however, that panel or expert consultation did not appear to occur in the following disputes involving Annex I(k): Panel Report, Brazil - Export Financing Programme for Aircraft WT/DS46/R (circulated 14 April 1999); Appellate Body Report, Canada-Measures Affecting the Export of Civilian Aircraft WT/DS70/AB/R (circulated 2 August 1999); Panel Report (circulated 14 April 1999); Panel Report, Canada-Export Credits and Loan Guarantees for Regional Aircraft WT/DS222/R (circulated 28 January 2002).

185 See above $n 146$ and surrounding text.

186 Decision of the Committee on Principles for the Development of International Standards, Guides and Recommendations with relation to Articles 2, 5 and Annex 3 of the Agreement (2002): WTO Doc G/ TBT/1/Rev.8. For a critical assessment of the Decision, see Rob Howse, 'A New Device for Creating International Normativity: The WTO Technical Barriers to Trade Agreement and "International Standards", , in Christian Joerges and Ernst-Ulrich Petersmann (eds.), Constitutionalism, Multilevel Trade Governance and Social Regulation (Hart Publishing, 2006) 383, 392-394.

187 For an analysis of the SPS Committee acting as agent of peer review, see Joanne Scott, The WTO Agreement on Sanitary and Phytosanitary Measures: A Commentary (OUP, 2007) 50ff.

188 WTO Doc G/SPS/R/47. 
These procedures emphasize transparency, accessibility and ongoing scrutiny of norms and benchmarks from international regimes, and are suggestive of emerging factors for WTO members to ensure appropriate regime interaction, a theme developed in Section 3. Such factors are important not only in the fishery subsidies negotiations and resulting disciplines, but also for the proposed regime interaction in the settlement of subsidies disputes.

\section{Settling disputes through consultation}

The third area of entrenched and ongoing links between the WTO and other international organizations is in proposals for the settlement of disputes about fisheries subsidies. The Chair's text adopts two procedures for dispute settlement. For disputes about prohibited subsidies, panels are constituted according to the current procedure of the SCM Agreement. ${ }^{189}$ For other disputes, panels are constituted according to the DSU. ${ }^{190}$ In both cases, if the dispute raises 'scientific or technical questions related to fisheries', the panel must seek advice from 'fisheries experts'. ${ }^{191}$ These experts are to be chosen by the panel in consultation with the disputing parties. The panel also has discretion to consult with international organizations. ${ }^{192}$

The provision for panel consultations with experts and international organizations is virtually identical to the dispute settlement provision adopted by the SPS Agreement, ${ }^{193}$ which was drafted after substantial disagreement between negotiators. The Cairns group of agriculture-producing WTO members wished to ensure that any consultation was in a personal capacity, because it wanted to minimize the role of international standardizing bodies in dispute settlement. ${ }^{194}$ Subsequent application of the SPS Agreement reveals that there is some uncertainty

189 As such, the panel may request the assistance of the Permanent Group of Experts (PGE), whose conclusions shall be accepted without modification: Chair's text, above n 78, Art. VIII.1, referring to SCM Agreement Art. 4. However, the PGE has yet to be consulted in the history of the SCM Agreement.

190 Chair's text, above n 78, Art. VIII.1, referring to SCM Agreement Article 30.

191 Ibid., Art. VIII.4. ('Where a dispute arising under this Annex raises scientific or technical questions related to fisheries, the panel should seek advice from fisheries experts chosen by the panel in consultation with the parties. To this end, the panel may, when it deems it appropriate, establish an advisory technical fisheries expert group, or consult recognized and competent international organizations, at the request of either party to the dispute or on its own initiative.') Rather than using Brazil's suggested language that the panel 'may' seek advice from fisheries experts, the Chair's text reproduces the United States' proposed language of 'should': see WTO Doc TN/RL/GEN79R3 (proposed Art. 7.1), cf TN/RL/GEN/145 (proposed Article 10).

192 Ibid. On one reading, draft Art. VIII.4 gives the panel discretion to consult with an advisory fisheries expert group or relevant international organization on scientific or technical matters. On another reading, the paragraph merely refers to the discretionary power of the panel to consult on the selection of fisheries experts. This is the interpretation preferred by the United States, which modified its initial proposal to clarify that FAO and other international organizations could be asked to provide assistance merely in identifying appropriate experts, and would not be called upon to provide expert opinions as organizations: WTO Doc TN/RL/GEN/145 (annotation to proposed Art. 10).

193 SPS Agreement, Art. 11.

194 See Motaal, above n 145, 864 and citations therein. 
about whether international organizations should be consulted only on the specific selection of experts ${ }^{195}$ or on a wider set of issues. ${ }^{196}$

One of the ways that SPS negotiators sought to balance the role of international standards was to remind WTO members of their unimpaired rights to resort to the good offices or dispute settlement mechanisms of these international agreements. ${ }^{197}$ Such a reminder is reproduced in the Chair's text, ${ }^{198}$ a provision that sits rather uneasily with the SCM Agreement's stipulation that no other specific action can be taken against a subsidy of another member. ${ }^{199}$

WTO members could have gone much further in designing inter-regime enforcement. An early proposal from the WWF, for example, promoted much closer interaction between a WTO dispute settlement panel and international organizations. ${ }^{200}$ The WWF proposed that a permanent group, comprised of experts from the FAO, UNEP, RFMOs, and NGOs, would sit at the WTO and would have the authority to make binding rulings on matters outside of the traditional competence of the WTO. ${ }^{201}$ This proposal reflects other suggestions for shared adjudicative capacities made in the general trade and environmental context. ${ }^{202}$

The WWF suggestion was not accepted by the Rules Group, but even current arrangements could promote authority sharing with other regimes to some extent. For example, if a panel adjudicating on an alleged prohibited subsidy is required to assess whether subsidies are benefiting fishing activity for stocks that are in an 'unequivocally overfished condition', ${ }^{203}$ it could consult the existing Permanent Group of Experts (PGE) for a binding determination. The PGE has the discretion to draw on a wide range of sources for assistance $;^{204}$ depending on the PGE's initiative, this could include consultations between the PGE and international organizations, scientific experts, and NGOs. In addition, there are a number of other methods by which a WTO adjudicating body can seek information from other regimes in resolving fisheries subsidies disputes. This includes information from amicus briefs and from the submissions of the disputing parties themselves.

195 See Appellate Body Report, Australia - Measures Affecting Importation of Salmon WT/DS18/AB/ R (circulated 20 October 1998); Appellate Body Report, EC-Hormones (US and Canada) WT/DS26 and DS48/AB/R (circulated 16 January 1998); Appellate Body Report, Japan-Measures Affecting Agricultural Products WT/DS/76/AB/R (circulated 22 February 1999); Panel Report WT/DS76/R (circulated 27 October 1998).

196 Panel Report, EC-Measures Affecting the Approval and Marketing of Biotech Products Panel Report WT/DS291/R, WT/DS292/R, WT/DS293/R (circulated 29 September 2006), para. 3.1. But note that this consultation was limited in other ways, as considered in Young, above $\mathrm{n} 97$.

197 SPS Agreement, Art. 11.3.

198 Chair's text, above n 78, Art. VIII.5.

199 See SCM Agreement, Art. 32.1.

200 Schorr, above n 68, 105.

201 Ibid.

202 See, e.g., Perez, above n 104, 98 and citations therein with respect to UNEP acting as a representative on WTO panels.

203 Chair's text, above n 78, Art. I.2.

204 The PGE may consult with and seek information from any source it deems appropriate: SCM Agreement Article 24.5. But see above n. 189 and surrounding text. 
The institutional provision for panel consultation on fisheries issues is of course interrelated with the normative status of the fisheries regimes in the disciplines. For example, for a self-contained standard, such as the 'equivocally overfished' standard proposed by the EC, dispute settlement bodies retain full discretion to interact with other regimes. For standards that directly incorporate the norms of international organizations, such as the FAO international plan of action on IUU fishing, adjudication inevitably requires WTO adjudicating bodies to refer to those regimes. This gives further complexity to the regime interaction in the implementation of the disciplines and the adjudication of potential violations, as is explored in the next section.

\section{Implications for the WTO and international law}

Section 2 contrasted three models of information sharing and documented the influence of the third model, where deliberation by state and non-state actors influenced the fisheries subsidies negotiations. The section then described three proposed arrangements for collaboration with other regimes in the implementation of the rules: the classification of subsidies, the imposition of fisheries management conditionality, and the settlement of disputes. Comparisons with the SCM Agreement's provision on export credit practices and the TBT and SPS Agreements' reliance on external standards demonstrated the ongoing need for information sharing and inter-regime scrutiny. This section places these findings in theoretical context and discusses wider implications, both at the level of detail of the implementation and adjudication of the subsidy disciplines themselves, and more generally with respect to the fragmented international legal system.

\section{Regime interaction as deliberation and scrutiny}

The current responses to the Chair's text suggest that incorporating the law of the sea and FAO regimes into the fisheries subsidies disciplines will be as controversial as the WTO's previous adoption of norms and benchmarks from international standard-setting bodies and the OECD. This controversy resides, in part, on the concern by WTO members to retain full control over the rules, and the view that the legitimacy of the rules arises only if all WTO members have agreed to them.

As described in Section 2, the extreme form of these views imposes a prerequisite of parallel membership between interacting institutions, as demonstrated by Taiwan's rejection of the role of the FAO in the fisheries subsidies disciplines. It also leads to the view that the WTO should refrain from disciplining ecologically harmful fisheries subsidies because of its lack of expertise in assessing fisheries sustainability. ${ }^{205}$ This extreme position, which has been manifest in other areas of 
WTO law, is impossible to maintain in both theoretical and practical terms. ${ }^{206} \mathrm{Such}$ disconnect between legal regimes does not exist in real-world problems, where economic decisions of subsidizing states have undeniable environmental effects.

In response, I suggest that WTO members' concerns can be addressed by procedures that ensure that, if fisheries regimes are accorded authority by WTO rules, 'authority and contestability go hand in hand'. ${ }^{207}$ Procedures that direct WTO members to scrutinize the rule making and operation of non-WTO regimes, or at least counteract current WTO structures that preclude such scrutiny, are of particular interest. There is growing evidence of the interest of WTO members in these procedures, both in the actual practice in the TBT and SPS Committees ${ }^{208}$ and in the proposed roles for the SCM Committee (in general ${ }^{209}$ and in fisheries subsidies reform). For the fisheries subsidies disciplines, in particular, the SCM Committee will maintain surveillance over the FAO's peer review of WTO members' fisheries management practices. ${ }^{210}$

These techniques suggest an emerging role for regime interaction by WTO bodies in the implementation of rules, and point to further scope for ongoing scrutiny. The SCM Committee may have a greater role, for example, in scrutinizing the operation of the fisheries organizations that are instituting the relevant fisheries 'best practices'. The reference in the Chair's text to the Fish Stocks Agreement, the FAO Code of Conduct, and the Compliance Agreement is attractive not only because these instruments were developed in an accessible and transparent way, but also because they seek to promote substantive openness and transparency in fisheries management. ${ }^{211}$ The Code of Conduct, for example, was developed in a spirit of collaboration and is subject to ongoing review, ${ }^{212}$ and emphasizes the need for ongoing collaboration by stakeholders in the Code's implementation. ${ }^{213}$ Less convincing, perhaps, are the references in the Chair's text to technical guidelines and plans of actions for the implementation of these instruments. The development of these standards is a rather more closed affair.

206 See above $\mathrm{n} 101$ and surrounding text.

207 The phrase comes from Joanne Scott, who compares the practice of the European Court of Justice and the WTO Appellate Body in scrutinizing international standards before according them authority: Joanne Scott, 'International Trade and Environmental Governance: Relating Rules (and Standards) in the EU and the WTO' (2004) 15 European Journal of International Law 307.

208 As noted above n 186 and $\mathrm{n} 187$ and surrounding text.

209 See especially in subjecting the OECD Export Credit Arrangement to additional notification and surveillance requirements, as noted above $\mathrm{n} 183$ and surrounding text.

210 Chair's text, above n 78, Art. V.1. This role will co-exist with the SCM Committee's ongoing surveillance of member measures: see, e.g., requirements that WTO members notify the SCM Committee of any 'green-box' or other measure that they consider to be exempt from disciplines (Art. VI) and rights for other members to be kept informed (Art. VI.5 and Art. V.2.). Note also that the procurement of access rights for fisheries are to be made public and notified to the SCM Committee (Art. VI.2).

211 See, e.g., Fish Stocks Agreement Art. 12, which seeks to promote transparency in the activities of RFMOs.

212 Details on the development of the FAO Code of Conduct are set out in Annex 1 of the Code. On the review of the Code, see FAO Code of Conduct Art. 4.3.

213 See Ibid., Art. 4.1; see also Art. 11.3.2. 
The Chair's text is currently silent on requiring instruments such as technical guidelines to be publicly accessible, transparent in their development, or inclusive in membership for all relevant WTO members. Such a requirement would be especially valuable, especially if indigenous management institutions are to replace international best practices in special and differential treatment, as has been proposed by some developing countries. ${ }^{214}$ Although indigenous institutions are potentially useful in recognizing the special conditions of artisanal fisheries, they still require scrutiny to ensure that sustainability in fisheries is being maintained.

Similarly, the proposed use of the FAO definition for IUU fishing may be appropriate if the relevant RFMO conservation measures remain transparent and subject to ongoing scrutiny, and if the plan of action continues its current emphasis on participation, coordination, and non-discrimination. ${ }^{215}$ The absence of a requirement for consensus in the adoption of the FAO plan of action does not eliminate its role; rather, such an absence might lead to a more in-depth scrutiny of its internal procedures by the SCM Committee or an adjudicating body. This has the added benefit of removing the risk of a vacuum of fisheries and conservation standards created due to the seemingly impossible aim of reaching consensus for their adoption.

It is tempting to conclude that the deliberation and scrutiny by the SCM Committee and adjudicating panels will ensure appropriate regime interaction between the WTO and the FAO and other fisheries bodies. However, one of the major findings of my analysis of the three models of negotiations in Section 2 was that inter-regime learning depended on an additional set of actors besides states and international organizations. This suggestion that regime scrutiny will be undertaken by a network of interested parties has implications for the notion of regimes and their participants, both for the WTO disciplines and for international law.

\section{Revised conceptions of regimes and their participants}

Regime interaction is not limited to official members of regimes, such as WTO members and the states that are members of the FAO (many, but not all, of whom are the same states). ${ }^{216}$ Contestation of fisheries regimes by non-state actors has occurred in the negotiations to date, and the third model of inter-regime learning described in Section 2 referred to a range of deliberative forums spatially and temporally linked to the Rules Group that have influenced the Chair's text. Interregime contestation will also occur in the enforcement of the disciplines through consultative and amicus arrangements with WTO panels, notwithstanding the rejection by the Chair's text of novel proposals for authority-sharing arrangements between experts from a range of intergovernmental and non-state organizations. 
An enhanced role for non-state actors in inter-regime scrutiny is absent from much of the literature responding to the need to link 'non-trade' interests with the WTO. One prescription, for example, suggests institutional reform of the WTO that includes the establishment of new 'departments' with different competencies, such as environment or competition. ${ }^{217}$ While enhancing regime interaction, such reform assumes that all relevant interests are ascertainable and conveyed by WTO members.

By contrast, recent literature on governance within the European Union and other jurisdictions has given increased attention to the involvement in law making of actors without 'representative' functions, who are nonetheless 'affected' by policy areas. ${ }^{218}$ The 'new governance' literature investigates how laws are made and shaped by practices and processes that fall outside traditional conceptions of regulation. The literature includes analysis of inclusive decision making by state and non-state parties and calls attention to 'governing councils' that collect and distribute experiences gathered within a variety of networks to promote mutual learning. ${ }^{219}$ Such insights are increasingly applied to supranational and international law as well as international standard setting. ${ }^{220}$ Similarly, the idea of 'adaptive governance' promotes attention to the learning and review functions of bodies such as the WTO. ${ }^{221}$ Some even claim that such governance should be termed 'post-sovereign', because it is non-exclusive, non-hierarchical and postterritorial. ${ }^{222}$

This theoretical framework is supported by various examples in the negotiation of WTO disciplines on fisheries subsidies. In the framing of the rules, UNEP and

217 Andrew Guzman, 'Global Governance and the WTO' (2004) 45 Harvard International Law Journal 303, 335.

218 Gráinne de Búrca and Joanne Scott, 'Introduction: New Governance, Law and Constitutionalism', in Gráinne de Búrca and Joanne Scott (eds.), Law and New Governance in the EU and the US (2006) 1; see also symposium: 'Narrowing the Gap? Law and New Approaches to Governance in the European Union' (2007) 13: 3 Columbia Journal of European Law.

219 See, e.g., Michael Dorf and Charles Sabel, 'A Constitution of Democratic Experimentalism' (1998) 98 Columbia Law Review 267 (arguing that mutual learning among the decentralized bodies of the United States public administration, and involving citizens in decisions that affect them, enhances the accountability and efficiency of decision making).

220 See, e.g., Joshua Cohen and Charles Sabel, 'Sovereignty and Solidarity: EU and US', in Jonathan Zeitlin and David Trubek (eds.), Governing Work and Welfare in a New Economy: European and American Experiments (2003) 345. See further in relation to international harmonization, Harm Shepel, The Constitution of Private Governance: Product Standards in the Regulation of Integrating Markets (2005) 412. See also Joanne Scott, above n 207; Patrizia Nanz, 'Democratic Legitimacy and Constitutionalisation of Transnational Trade Governance: A View from Political Theory', in Christian Joerges and Ernst-Ulrich Petersmann (eds.), Constitutionalism, Multilevel Trade Governance and Social Regulation (Hart Publishing, 2006) 60, 80.

221 Rosie Cooney and Andrew Lang, 'Taking Uncertainty Seriously: Adaptive Governance and International Trade' (2007) 18 European Journal of International law 523. See also Peter Haas, 'Introduction: Epistemic Communities and International Policy Coordination' (1992) 46 International Organization 1.

222 See, e.g., Bradley Karkkainen, 'Post-Sovereign Environmental Governance' (2004) 4 Global Environmental Politics 72, 81. 
the WWF acted as 'governing councils' that shared crucial information and promoted learning to further democratic experimentalism. These workshops were open to all stakeholders and sought to provide forums for political debate. The deliberations were documented and forwarded to the Rules Group, and there was an apparent reliance by WTO members on the deliberations in the drafting of text. This was a kind of 'public-civil society partnership' influencing the development of WTO law, ${ }^{223}$ and may suggest an inclusivity in WTO decision making for which there is significant demand. ${ }^{224}$ The evidence also confirms UNEP's role in encouraging 'mutual supportiveness' of trade and environment policies. ${ }^{225}$

\section{Contestability, accountability, and stability}

The conception of information sharing, inter-regime scrutiny, and experimentalism described here promotes deliberation by state and non-state actors that will be affected by the new rules. It also recognizes the need for expertise to be shared to enhance understanding of existing processes and to counter cultural and disciplinary differences and insensitivities of particular regimes. Such a conception accords with mainstream accounts of law making. It is more controversial, however, to apply this conception to the ongoing implementation of disciplines and the adjudication of disputes. Indeed, the emphasis in this article on the contestation of norms may seem counter-productive for a legal system.

Authority is usually given as a guarantee of order and the law's role is to provide stability and predictability. Yet my conclusions call for ongoing regime interaction and scrutiny by WTO members and non-state actors. Informed by existing arrangements between the WTO and organizations such as the OECD and product standard-setting bodies, I have pointed to potential sites of contestation within bodies such as the SCM Committee. I have suggested, for example, that internationally recognized best practices for fisheries management and conservation may be appropriate as benchmarks for the fisheries subsidies rules if they can be contested by such bodies. Moreover, the openness, transparency, and accountability of these processes are more important in ensuring legitimacy than attempts to ensure parallel membership or consensual institutional interaction by WTO members.

These processes are open-ended and have no obvious conclusions. Such uncertainty risks the stability guaranteed by law, and arguably exposes the fisheries subsidies disciplines to a case-by-case approach that is more vulnerable to the power relations within particular disputes. Indeed, in the domestic context,

223 Cf. Shaffer's work on public-private partnerships which relates to corporate actors in the WTO: see Gregory Shaffer, Defending Interests: Public-Private Partnerships in WTO Litigation (2003).

224 For the comparatively early advocacy for the integration of stakeholders in the WTO, see G. Richard Shell, 'Trade Legalism and International Relations Theory: An Analysis of the World Trade Organization' (1995) 44 Duke Law Journal 829; see also G. Richard Shell, 'The Trade Stakeholders Model and Participation by Nonstate Parties in the World Trade Organization' (1996) 17 University of Pennsylvania Journal of International Economic Law 359.

225 See above n 128 and accompanying text. 
democratic experimentalism has been criticized as jeopardizing stabilizing democratic institutions, such as the rule of law. ${ }^{226}$

The risk to stability posed by ongoing deliberation and scrutiny is real. In response, however, it is important not to analogize too closely the domestic and international legal contexts and the assumptions each make about authority. By contrast to domestic liberal democracies, the international system lacks overarching norms and is instead dominated by multiple and sometimes fragmented norms and institutions. As such, a departure from domestic constitutional ideals and towards open and accountable procedures of regime interaction may be justified. Close empirical engagement is required to understand and theorize such procedures; admittedly, the present study will be richer after the rules are agreed and the complex work by multiple actors has progressed. The premise, and hope, of this article is that the inter-regime scrutiny and contestation it describes represents a new and effective approach to global problems, such as fisheries depletion, that involve multiple legal regimes.

These findings also highlight the need for greater attention to the role, institutional support, and continued viability of participants in the making and implementation of international law across a number of regimes. For secretariat staff and other informal groupings of officials, there is a need for further analysis of their accountability and transparency. ${ }^{227}$ Similarly, the role of experts in transnational governance requires extended analysis, in particular to forestall a 'managerial' approach to questions of fragmentation. ${ }^{228}$ For example, if fisheries experts are to facilitate learning and the ongoing scrutiny of various legal responses to declining fish stocks, it is important that they maintain, at the very least, openness about the sources of their information and research methodologies. Similarly, although the standards of accountability for non-governmental organizations advocating for ecological preferences are different from the standards expected of states, ${ }^{229}$ it is important that they are open about whom (or what) they seek to represent. ${ }^{230}$ It is equally important to recognize the transitory nature of 'crisis' advocacy networks, and the risk that the groups that have coalesced around the

226 William Scheuerman, 'Democratic Experimentalism or Capitalist Synchronization? Critical Reflections on Directly-Deliberative Polyarchy' (2004) 17 Canadian Journal of Law and Jurisprudence 101.

227 As promoted by Benedict Kingsbury, Nico Krisch, and Richard Stewart, 'The Emergence of Global Administrative Law' (2005) 68 Law and Contemporary Problems 15 (responding in part to Slaughter, above n 116).

228 See David Kennedy, 'The Mystery of Global Governance' (2008) 34 Ohio Northern University Law Review 827, 846-7; see also Martti Koskenniemi, 'The Fate of Public International Law: Between Technique and Politics' (2007) 70 Modern Law Review 1.

229 See Sasha Courville, 'Understanding NGO-Based Social and Environmental Regulatory Systems: Why We Need New Models of Accountability', in Michael W. Dowdle (ed.), Public Accountability: Designs, Dilemmas and Experiences (CUP, 2006) 271.

230 Arguably, this was recognized by the WTO Appellate Body Secretariat when it issued a much maligned directive to potential amicus in the Asbestos litigation. By comparison, the UN requires NGOs to reveal the sources of voluntary contributions and explain other sources of funding (see UN Charter Art. 71 
issue of fisheries subsidies may well move on to address other sustainability goals after the completion of the negotiations. ${ }^{231}$

\section{Conclusion}

The proliferation and fragmentation of rules and institutions in international law has given rise to a number of challenges for those seeking to address global problems, such as fisheries depletion. Much scholarly attention has been given to challenges relating to resolving conflicting norms, ${ }^{232}$ but this article has instead focused on the challenges for international law making and implementation.

My analysis of WTO members' attempts to make and implement fisheries disciplines rejects rhetorical suggestions that interaction between the WTO and other legal regimes depends upon the express or implied consent of regime members. It instead confronts problems of fragmentation by promoting deliberation, information sharing, learning, the use of benchmarks and institutional interaction by a wider set of participants. Informed in part by existing arrangements between the WTO and the OECD and standard-setting bodies, it suggests that the legitimacy of the involvement of this wider set of participants, which includes intergovernmental organizations, NGOs, and fisheries advocacy groups that do not have representative functions, is based on the need for deliberation and on-going inter-regime scrutiny. In this vein, I have shown that the Chair's text containing proposed fisheries subsidies disciplines has been influenced by a 'governing council' that included a wider number of participants than just WTO members.

These findings recast current attempts to understand legal fragmentation and may even contain the potential to pre-empt further fragmentation. First, the coordination between international regimes cannot rest solely on the initiatives of states, notwithstanding innovative attempts at domestic policy coordination. Secondly, historic attention on the coordination between international organizations demands reinvigoration, ${ }^{233}$ especially to confront legal questions about their implied powers. ${ }^{234}$ Thirdly, the participants of regime interaction must include stakeholders, such as non-state advocacy groups and epistemic communities, to provide much-needed deliberative engagement. This suggests a different legal

and ECOSOC Resolution 1996/31 adopted in 1996; see further http://esa.un.org/coordination/ngo/new/ index.asp (last accessed 13 April 2008)).

231 See, on growth of networks to address 'crisis' situations, and an admonishment not to rely on such networks in everyday governance, Helen Hershkoff and Benedict Kingsbury, 'Crisis, Community, and Courts in Network Governance: A Response to Liebman and Sabel's Approach to Reform of Public Education' (2003) 28 NYU Review of Law and Social Change 319.

232 See above $\mathrm{n} 17$ and accompanying text.

233 See Jenks above n 103.

234 See further my Trading Fish, Saving Fish: The Interaction between Regimes in International Law (Cambridge University Press, forthcoming 2010). 
framework than the 'traditional, State-centric international law' considered by the International Law Commission in its seminal study. ${ }^{235}$

Historically, international lawyers responded to potential situations of legal fragmentation by proposing wide-ranging consultations before the drafting of new instruments. They urged state representatives to 'form the habit of regarding proposed new instruments from the standpoint of their effect on the international statute book as a whole'. ${ }^{236}$ This article has similarly endorsed inter-regime consultation and coordination, but it has gone further. The fisheries subsidies negotiations show that it is not sufficient for trade delegates to have regard to other international regimes. Instead, a wide range of participants must learn, scrutinize and contest norms and standards relating to fisheries management in an ongoing process of regime interaction. Whether this process is conceived as legal wrangling between regimes, or as political contestation about the definitions of regimes themselves ${ }^{237}$ this article suggests a need for a greater awareness of how knowledge is produced and by whom, and how legal oversight will continue and by whom, in crucial issues of fisheries governance and beyond.

237 See Koskenniemi, above n 228, 29. 


\section{University Library}

\section{- M M N E R VA A gateway to Melbourne's research publications}

Minerva Access is the Institutional Repository of The University of Melbourne

Author/s:

Young, MA

Title:

Fragmentation or interaction: the WTO, fisheries subsidies, and international law

Date:

2009-10-01

Citation:

Young, M. A. (2009). Fragmentation or interaction: the WTO, fisheries subsidies, and international law. WORLD TRADE REVIEW, 8 (4), pp.477-515. https://doi.org/10.1017/ S1474745609990140.

Publication Status:

Published

Persistent Link:

http://hdl.handle.net/11343/33005 